\title{
Intra- and Intergeneric Similarities of Agrobacterium Ribosomal Ribonucleic Acid Cistrons
}

\author{
J. DE SMEDT AND J. DE LEY \\ Laboratory of Microbiology and Microbial Genetics, Faculty of Sciences, State University, \\ B-9000 Ghent, Belgium
}

\begin{abstract}
We prepared hybrids between ${ }^{14} \mathrm{C}$-labeled ribosomal ribonucleic acid (rRNA) from either Agrobacterium tumefaciens ICPB TT111 or A. rhizogenes ICPB TR7, and deoxyribonucleic acid (DNA) from a great variety of reference gramnegative and gram-positive bacteria. Each hybrid was described by (i) its $T_{m(e)}$, the temperature at which $50 \%$ of the hybrid was denatured, and (ii) percentage of rRNA binding, i.e., micrograms of ${ }^{14} \mathrm{C}$-labeled rRNA duplexed per $100 \mu \mathrm{g}$ of filter-fixed DNA. Each taxon occupied a definite area on the rRNA similarity map. The size and shape of this area depended on the phenotypic and genetic heterogeneity of the taxon. There appeared to be a correlation between $T_{m(e)}$ of the heterologous hybrids and the overall phenotypic similarities of the organisms and taxa involved. $T_{m(e)}$ values above $65^{\circ} \mathrm{C}$ were taxonomically most meaningful. DNA:rRNA hybridizations condensed all strains from a genus in one narrow cluster; the method had little resolution to distinguish species within a genus, but it seemed to be a very useful approach to detect remote relationships at the inter- and suprageneric level, for taxonomic and identification purposes. The hybrid parameters of Azotomonas fluorescens, Mycoplana bullata, Mycoplana dimorpha, Phyllobacterium, two misnamed "Chromobacterium lividum" strains from leaf-nodulating plants, two misnamed agrobacteria from the Baltic Sea, and a few misnamed "Achromobacter" strains were all in the vicinity of Agrobacterium and Rhizobium. We suggest that all of these organisms are remote relatives and belong in the family of the Rhizobiaceae. Azotomonas insolita NCIB 9749 is misnamed; it is an Agrobacterium. Several organisms which had been misnamed Agrobacterium formed DNA:rRNA hybrids with properties outside the Agrobacterium area.
\end{abstract}

The nature and degree of the phylogenetic relationships between most bacterial genera are not known, except for a limited number of cases, where such relationships can be deduced indirectly from comparative biochemistry (13), numerical analysis of phenotypic data (65), and deoxyribonucleic acid (DNA):DNA hybridizations (14, 21). Most bacterial genera, however, are evolutionarily too far removed from each other to form stable DNA:DNA hybrids; the last technique is in general useful either within a genus such as Agrobacterium (16, 17), or between genera which did not diverge too much, such as in the Enterobacteriaceae (7).

The detection of more remote relationships between bacterial taxa will require other techniques. One of them is the comparison of amino acid sequences of small proteins. It is well established that the amino acid sequences of $\mathrm{mi}$ tochrondrial $c$ cytochromes from animals correlate well with the overall phylogenetic relationships of the organisms, clarified by other methods $(12,49)$. The other way around, amino acid sequencing of bacterial cytochromes and other small proteins might reveal the phylogenetic relationships between bacterial genera (12). This area is in full expansion (3). However, it may take a very long time and much effort to solve this single aspect of bacterial relationships.

It seemed to us that a faster way than determining amino acid sequences in homologous gene products consisted in comparing base sequence similarities between homologous genes. The advantage of the latter approach was that the actual sequences need not to be known. The obvious choice was to compare ribosomal ribonucleic acid (rRNA) cistrons from several genera by DNA:rRNA hybridizations. rRNA cistrons are conserved: their base sequences have changed less than those of the bulk of the genes constituting the bacterial genome (26, $27,53,71)$. Various degrees of rRNA sequence similarities have been detected between phenotypically quite different bacteria $(39,53,54$, $56,57)$, but extensive taxonomic improvements 
have not been achieved. rRNA homology, determined by preventing homologous DNA: rRNA duplexing in the presence of excess heterologous competing rRNA, is useful to subdivide large and heterogeneous genera, such as Pseudomonas (58) and Clostridium (40).

We shall examine whether bacterial rRNA similarities are valuable parameters to reveal taxonomic relatedness at the generic and suprageneric levels. In the present paper we shall compare the rRNA cistrons of Agrobacterium within the genus and with those of a number of other bacterial genera. Several conclusions were confirmed by DNA:DNA hybridizations and by protein electropherograms.

\section{MATERIALS AND METHODS}

Bacterial strains and growth media. The strains used are listed in Table 1 (see also Table 6). The bacteriological purity was checked by plating, and by examination of living and gram-stained cells. For mass cultures, cells were grown in Roux flasks on media solidified with $2.5 \%$ agar for 2 to 3 days at $28^{\circ} \mathrm{C}$. A few slow-growing strains were grown for at most 4 to 6 days. The compositions of all growth media used are summarized in Table 2. After growth the cells were harvested, washed, and lyophilized.

We received three Phyllobacterium strains from D. Knösel, $P$. rubiacearum strain LMG1 and $P$. myrsinacearum LMG2 and LMG3. Upon plating we detected two colony types in each strain, labeled $t_{1}$ and $t_{2}$. Strain LMG1 $t_{2}$ (sequence number 11 [see Table 1]; henceforward, these numbers will be indicated as, for example, "number 11" following the strain, was identified in this laboratory as a contaminating Agrobacterium. The five remaining strains (numbers 50 to 54) were included as Phyllobacterium.

Preparation of ${ }^{14} \mathrm{C}$-labeled rRNA. The organisms were inoculated in $100 \mathrm{ml}$ of liquid medium A (Table 2), in a broad-bottomed Erlenmeyer flask with a Klett tube as side arm. Shaking provided good aeration. Growth was followed turbidimetrically in a Klett colorimeter at $660 \mathrm{~nm}$. A $100-\mu \mathrm{Ci}$ amount of [2$\left.{ }^{14} \mathrm{C}\right]$ uracil (The Radiochemical Centre, Amersham, Buckinghamshire, England) in $5 \mathrm{ml}$ of $0.01 \mathrm{M}$ phosphate buffer $(\mathrm{pH} 7.0)$ was sterilized separately through a membrane filter and added at the start of the log phase. The cells were harvested near the end of the exponential phase and washed. ${ }^{14} \mathrm{C}$-labeled rRNA was prepared and purified as described by De Ley and De Smedt (20). The 23S (see below) and $16 \mathrm{~S}$ fractions were collected separately and dialyzed at $4^{\circ} \mathrm{C}$ three times against 2 liters of $2 \times \mathrm{SSC}$ buffer. The fractions were preserved at $-12^{\circ} \mathrm{C}$. The specific activities of Agrobacterium tumefaciens TT111 ${ }^{14} \mathrm{C}-$ labeled rRNA and of Agrobacterium rhizogenes TR7 ${ }^{14} \mathrm{C}$-labeled rRNA were $3,000 \mathrm{cpm} / \mu \mathrm{g}$ and 2,400 $\mathrm{cpm} / \mu \mathrm{g}$, respectively. These preparations contained less than $0.2 \%$ DNA and $1 \%$ protein.

Preparation of DNA. High-molecular-weight native DNA was prepared by a combination of the methods of Marmur (50) and Kirby $(43,44)$, as de- scribed by De Ley et al. (19). Several gram-positive and coryneform organisms lysed readily in the solvent described by Crombach (11): $0.033 \mathrm{M}$ tris(hydroxymethyl)aminomethane-0.001 M ethylenediaminetetraacetic acid ( $\mathrm{pH} 8$ ), containing $5 \mathrm{mg}$ of lysozyme per $\mathrm{g}$ of wet cells. The molecular weight of the DNA fragments was $5 \times 10^{6}$ to $10 \times 10^{6}$.

Fixation of single-stranded high-molecularweight DNA on membrane filters. We followed the fixation procedure as described by De Ley and Tytgat (24). We used Sartorius SM 11309 membrane filters. The charged filters were preserved at $4^{\circ} \mathrm{C}$ in vacuo (20).

Saturation hybridization between ${ }^{14} \mathrm{C}$-labeled rRNA and filter-fixed DNA: thermal stability of the DNA:rRNA hybrids. The basic aspects of the hybridization conditions, the nature of ribonuclease and its effect on hybridization, the effect of hybridization temperature on DNA leaching, the conditions of saturation hybridization, etc., have been reported in previous papers from this department $(20,24)$. For DNA:rRNA hybridization and hybrid stability we followed the methods of De Ley and De Smedt (20). A 10- $\mu \mathrm{g}$ amount of ${ }^{14} \mathrm{C}$-labeled rRNA was incubated in $1 \mathrm{ml}$ of $2 \times \mathrm{SSC}$ in $20 \%$ formamide, with a membrane filter carrying about $50 \mu \mathrm{g}$ of DNA, for $16 \mathrm{~h}$ at the stringent optimal hybridization temperature of $50^{\circ} \mathrm{C}$. After washing, the filters were treated with RNase. The thermal stability of the hybrid was determined in 5-degree steps from 50 to $90^{\circ} \mathrm{C}$ in $1.5 \times \mathrm{SSC}$ in $20 \%$ formamide. The amount of labeled material released at each step was counted in a Tri-Carb 3310 liquid scintillation spectrometer (Packard Instrument Co.) at $2^{\circ} \mathrm{C}$ for $50 \mathrm{~min} . T_{m(e)}$ is the temperature at which $50 \%$ of the hybrid was eluted. The total amount of ${ }^{14} \mathrm{C}$-labeled rRNA bound, after RNase treatment, expressed in micrograms of rRNA per $100 \mu \mathrm{g}$ of DNA retained on the filter, was called the "percentage of rRNA binding."

Chemical determination of DNA on the filter. In each series of hybridizations, a vial was included with buffer and a DNA filter, but without ${ }^{14} \mathrm{C}$-labeled rRNA. After the simulated hybridization step, the remaining fixed DNA was released from the filter by the method of Meys and Schilperoort (51) and determined by the method of Burton (10).

Preparation of ${ }^{14} \mathrm{C}$-labeled DNA. Labeled DNA was prepared as described before (35). The specific activities of ${ }^{14} \mathrm{C}$-labeled DNA from $A$. tumefaciens ICPB TT111 and B6 were 4,670 and $3,965 \mathrm{cpm} / \mu \mathrm{g}$ of DNA, respectively. Both were sheared in a French pressure cell to fragments of about $4 \times 10^{6}$ molecular weight and were heat-denatured before use.

DNA:DNA hybridizations: thermal stability of the DNA:DNA duplexes. We followed the method of De Ley and Tytgat (24), slightly modified, with 10 $\mu \mathrm{g}$ of single-stranded, sheared, ${ }^{14} \mathrm{C}$-labeled DNA in solution, and a membrane filter with about $22 \mu \mathrm{g}$ of single-stranded, high-molecular-weight, unlabeled DNA in $0.8 \mathrm{ml}$ of $2 \times \mathrm{SSC}$ buffer in $30 \%$ dimethyl sulfoxide $\left(\mathrm{Me}_{2} \mathrm{SO}\right)$. Incubation was for $16 \mathrm{~h}$ at the stringent temperature of $59^{\circ} \mathrm{C}$. After washing each filter in $2 \times \mathrm{SSC}-30 \% \mathrm{Me}_{2} \mathrm{SO}$, the thermal stability of each duplex was determined in the same $\mathrm{Me}_{2} \mathrm{SO}$ - 
TABLE 1. List of organisms used, their strain number, growth medium, DNA base composition, and properties of the DNA:rRNA hybrids with two Agrobacterium ${ }^{14} \mathrm{C}$-labeled rRNA references

\begin{tabular}{|c|c|c|c|c|c|c|c|c|}
\hline \multirow{3}{*}{$\begin{array}{l}\text { No. in } \\
\text { Fig. } 3 \\
\text { or } 4\end{array}$} & \multirow{3}{*}{$\begin{array}{l}\text { Organism used for } \\
\text { DNA prepn }\end{array}$} & \multirow{3}{*}{$\begin{array}{l}\text { Origin and } \\
\text { strain no. }\end{array}$} & \multirow{3}{*}{$\begin{array}{l}\text { Growth } \\
\text { medium }^{a}\end{array}$} & \multirow{3}{*}{$\begin{array}{l}\mathrm{Mol} \% \\
\mathrm{G}+\mathrm{C}^{b}\end{array}$} & \multicolumn{4}{|c|}{ Hybridization with rRNA from: } \\
\hline & & & & & \multicolumn{2}{|c|}{$\begin{array}{c}\text { Agrobacterium } \\
\text { tumefaciens } \\
\text { TT111 }\end{array}$} & \multicolumn{2}{|c|}{$\begin{array}{c}\text { Agrobacterium } \\
\text { rhizogenes } \\
\text { TR7 }\end{array}$} \\
\hline & & & & & $T_{m(e)}$ & $\begin{array}{l}\text { \% bind- } \\
\text { ing }\end{array}$ & $T_{m(e)}$ & $\begin{array}{l}\text { \% bind- } \\
\text { ing }\end{array}$ \\
\hline 1 & Agrobacterium tumefaciens & ICPB TT111 & A & 60.6 & 81 & 0.19 & 77 & 0.20 \\
\hline 2 & Agrobacterium tumefaciens & ATCC 4452 & A & 60.9 & 80 & 0.19 & & \\
\hline 3 & Agrobacterium tumefaciens & ATCC 11156 & A & 60.8 & 81 & 0.14 & & \\
\hline 4 & Agrobacterium tumefaciens & Beardsly $\mathrm{H} 5$ & A & 59.7 & 79 & 0.18 & 76 & 0.18 \\
\hline 5 & Agrobacterium tumefaciens & ICPB TT7 & A & 59.6 & 81 & 0.24 & & \\
\hline 6 & Agrobacterium tumefaciens & C.58 & A & 59.9 & 80.5 & 0.22 & & \\
\hline 7 & Agrobacterium tumefaciens & T37 & A & 60.2 & 79.5 & 0.13 & 77 & 0.16 \\
\hline 8 & Agrobacterium tumefaciens & $3 / 1$ & A & 61.6 & 80 & 0.24 & 77.5 & 0.22 \\
\hline 9 & Agrobacterium tumefaciens & NCPPB 925 & A & 60.1 & 80 & 0.20 & 77 & 0.20 \\
\hline 10 & Agrobacterium tumefaciens & CIP B6 & A & 60.2 & & & 77 & 0.16 \\
\hline 11 & Agrobacterium sp. & LMG1 t2 & B & 60.3 & 80.5 & 0.13 & & \\
\hline 12 & Agrobacterium sp. & 0363 & A & 60.3 & 79.5 & 0.21 & 76.5 & 0.18 \\
\hline 13 & Agrobacterium sp. & 4.1 & C & 62.5 & 80.5 & 0.14 & 77 & 0.15 \\
\hline 14 & Agrobacterium radiobacter & $\mathrm{M} 2 / 1$ & A & 61.0 & 80 & 0.18 & 77 & 0.18 \\
\hline 15 & Agrobacterium radiobacter & ATCC 13332 & $\mathbf{A}$ & 60.1 & & & 77 & 0.22 \\
\hline 16 & Agrobacterium tumefaciens & NCPPB 794 & A & 61.3 & 77 & 0.15 & 80.5 & 0.17 \\
\hline 17 & Agrobacterium rhizogenes & ICPB TR7 & A & 61.4 & 78 & 0.12 & 81 & 0.15 \\
\hline 18 & Agrobacterium rhizogenes & ICPB TR101 & A & 60.7 & 77 & 0.09 & 81 & 0.16 \\
\hline 19 & Agrobacterium rhizogenes & ATCC 15834 & A & 60.5 & & & 81 & 0.12 \\
\hline 20 & Agrobacterium rubi & ICPB TR2 & A & 58.8 & 80.5 & 0.20 & 76 & 0.15 \\
\hline 21 & Agrobacterium tumefaciens & EU6 & $\mathbf{A}$ & 58.8 & 77.5 & 0.19 & & \\
\hline 22 & Agrobacterium tumefaciens & NCPPB 1771 & $\mathbf{A}$ & 58.0 & 76 & 0.23 & 76 & 0.22 \\
\hline 23 & Agrobacterium tumefaciens & NCPPB 1650 & A & 57.8 & 78 & 0.18 & 76 & 0.18 \\
\hline 24 & Agrobacterium tumefaciens & NCPPB 930 & A & 58.9 & 78 & 0.16 & 76 & 0.18 \\
\hline 25 & Agrobacterium sp. & $175 / 1$ & $\mathbf{A}$ & 57.4 & 78 & 0.11 & & \\
\hline 26 & Agrobacterium sp. & $177 / 14$ & A & 57.6 & 78 & 0.12 & & \\
\hline 27 & $\begin{array}{l}\text { "Agrobacterium" ferrugi- } \\
\text { neum }\end{array}$ & Ahrens A43 & $\mathrm{T}$ & 64.8 & 73.5 & 0.06 & & \\
\hline 28 & "Agrobacterium" kieliense & Ahrens B9 & $\mathrm{T}$ & 50.6 & 72 & 0.08 & & \\
\hline 29 & "Agrobacterium" luteum & Ahrens B14 & $\mathrm{T}$ & 52.5 & 67 & 0.06 & & \\
\hline 30 & $\begin{array}{l}\text { "Agrobacterium" gelatinovo- } \\
\text { rum }\end{array}$ & Ahrens B6 & $\mathrm{U}$ & 57.6 & 67 & 0.07 & & \\
\hline 31 & "Agrobacterium" aggregatum & Ahrens B1 & $\mathrm{T}$ & 58.7 & 67.5 & 0.06 & & \\
\hline 32 & "Agrobacterium" agile & Ahrens A82 & $\mathrm{T}$ & 57.1 & 63.5 & 0.09 & & \\
\hline 33 & "Agrobacterium" sp. & $\begin{array}{l}\text { Sundman } 08= \\
113\end{array}$ & A & 62.0 & 61 & 0.07 & & \\
\hline 34 & "Agrobacterium" sp. & $\begin{array}{l}\text { Sundman } \mathrm{M} 14= \\
112\end{array}$ & $\mathbf{A}$ & 42.9 & 57 & 0.11 & & \\
\hline 35 & "Agrobacterium" azotophilum & (Ulloa) & $\mathbf{A}$ & 63.5 & 57 & 0.06 & & \\
\hline 36 & Rhizobium leguminosarum & USDA $316 C 10 A$ & $\mathrm{C}$ & 61.4 & 76 & 0.08 & 80 & 0.15 \\
\hline 37 & Rhizobium leguminosarum & 11.1 & $\mathrm{C}$ & 62.1 & 77 & 0.12 & 79.5 & 0.12 \\
\hline 38 & Rhizobium leguminosarum & 5.0 & $\mathrm{C}$ & 61.1 & 76 & 0.11 & 79 & 0.14 \\
\hline 39 & Rhizobium leguminosarum & USDA $3 F 3 C 1$ & D & 62.5 & 70.5 & 0.06 & 72 & 0.07 \\
\hline 40 & Rhizobium leguminosarum & USDA 3F6g2 & $\mathrm{C}$ & 61.3 & 72.5 & 0.06 & 74 & 0.06 \\
\hline 41 & Rhizobium meliloti & USDA 3D0a30 & D & 62.3 & 77 & 0.10 & 79 & 0.12 \\
\hline 42 & Rhizobium japonicum & 3.1 & I & 64.0 & 70 & 0.06 & 70 & 0.06 \\
\hline 43 & Rhizobium japonicum & USDA $316 \mathrm{n} 10$ & I & 63.3 & 67 & 0.03 & 70 & 0.04 \\
\hline 44 & Rhizobium japonicum & USDA 3I1b59 & I & 64.0 & 65 & 0.04 & 68 & 0.05 \\
\hline 46 & Azotomonas fluorescens & NCIB 9884 & B & 64.8 & 76 & 0.10 & & \\
\hline 47 & Azotomonas insolita & NCIB 9749 & $\mathbf{B}$ & 58.9 & 80 & 0.13 & & \\
\hline 48 & Mycoplana bullata & NCIB 9440 & B & 62.3 & 77 & 0.10 & 77 & 0.08 \\
\hline 49 & Mycoplana dimorpha & NCIB 9439 & B & 63.8 & 75 & 0.07 & 76.5 & 0.11 \\
\hline 50 & Phyllobacterium rubiacearum & LMG1 t1 & B & 61.3 & 72 & 0.07 & & \\
\hline 51 & $\begin{array}{l}\text { Phyllobacterium myrsina- } \\
\text { cearum }\end{array}$ & LMG2 t1 & $\mathbf{B}$ & 60.3 & 73 & 0.08 & & \\
\hline 52 & $\begin{array}{l}\text { Phyllobacterium myrsina- } \\
\text { cearum }\end{array}$ & LMG2 t2 & B & 59.8 & 73.5 & 0.08 & & \\
\hline 53 & $\begin{array}{l}\text { Phyllobacterium myrsina- } \\
\text { cearum }\end{array}$ & LMG3 t1 & B & 60.4 & 73 & 0.08 & & \\
\hline 54 & $\begin{array}{l}\text { Phyllobacterium myrsina- } \\
\text { cearum }\end{array}$ & LMG3 t2 & B & 59.6 & 72.5 & 0.08 & & \\
\hline 55 & Acetobacter aceti subsp. aceti & Ch 31 & $\mathrm{~N}$ & 59.6 & 66.5 & 0.09 & & \\
\hline 56 & $\begin{array}{l}\text { Gluconobacter oxydans subsp. } \\
\text { melanogenes }\end{array}$ & NCIB 8086 & $\mathbf{N}$ & 60.6 & 67 & 0.09 & & \\
\hline
\end{tabular}




\begin{tabular}{|c|c|c|c|c|c|c|c|c|}
\hline \multirow{3}{*}{$\begin{array}{l}\text { No. in } \\
\text { Fig. } 3 \\
\text { or } 4\end{array}$} & \multirow{3}{*}{$\begin{array}{l}\text { Organism used for } \\
\text { DNA prepn }\end{array}$} & \multirow{3}{*}{$\begin{array}{l}\text { Origin and } \\
\text { strain no. }\end{array}$} & \multirow{3}{*}{$\begin{array}{l}\text { Growth } \\
\text { medium }^{a}\end{array}$} & \multirow{3}{*}{$\begin{array}{l}\text { Mol \% } \\
\mathrm{G}+\mathrm{C}^{b}\end{array}$} & \multicolumn{4}{|c|}{ Hybridization with rRNA from: } \\
\hline & & & & & \multicolumn{2}{|c|}{$\begin{array}{c}\text { Agrobacterium } \\
\text { tumefaciens } \\
\text { TT11 }\end{array}$} & \multicolumn{2}{|c|}{$\begin{array}{l}\text { Agrobacterium } \\
\text { rhizogenes } \\
\text { TR7 }\end{array}$} \\
\hline & & & & & $T_{m(e)}$ & $\begin{array}{c}\% \text { bind- } \\
\text { ing }\end{array}$ & $T_{m(e)}$ & $\begin{array}{l}\% \text { bind- } \\
\text { ing }\end{array}$ \\
\hline 57 & $\begin{array}{c}\text { Zymomonas mobilis subsp. } \\
\text { mobilis }\end{array}$ & $\mathrm{Z} 1$ & $\mathrm{Y}$ & 48.8 & 68 & 0.16 & & \\
\hline 58 & Beijerinckia fluminensis & & $\mathrm{V}$ & 56.2 & 67 & 0.12 & & \\
\hline 59 & Beijerinckia indica & & V & 54.7 & 67.5 & 0.09 & & \\
\hline 60 & "Chromobacterium" lividum & NCTC 10590 & $\mathrm{X}$ & 61.1 & 66.5 & 0.06 & & \\
\hline 61 & "Chromobacterium" lividum & NCTC 10591 & $\mathrm{X}$ & 63.0 & 67.5 & 0.08 & & \\
\hline 62 & Chromobacterium lividum & NCTC 9796 & $\mathrm{X}$ & 65.5 & 59 & 0.11 & & \\
\hline 63 & Chromobacterium lividum & Sneath DA & $\mathrm{x}$ & 66.1 & 58 & 0.10 & 57.5 & 0.17 \\
\hline 64 & Chromobacterium violaceum & NCTC 9757 & $\mathbf{X}$ & 67.2 & 60 & 0.15 & & \\
\hline 65 & "Achromobacter" hartlebii & NCIB 8129 & B & 62.8 & 77.5 & 0.09 & & \\
\hline 66 & "Achromobacter" sp. & AB 1196 & $\mathrm{~A}$ & 59.2 & 73 & 0.12 & 73 & 0.17 \\
\hline 67 & "Alcaligenes" sp. & AB 940 & A & 58.0 & 73 & 0.12 & & \\
\hline 68 & "Achromobacter" sp. & AB 1293 & $\mathrm{~A}$ & 58.8 & 72.5 & 0.10 & & \\
\hline 69 & "Achromobacter"sp. & Ruiter 1 & B & 53.0 & 63.5 & 0.11 & & \\
\hline 70 & "Achromobacter" sp. & Ruiter 5 & B & 53.7 & 62 & 0.11 & & \\
\hline 71 & Achromobacter denitrificans & M 250 & B & 67.7 & 60 & 0.04 & 58.5 & 0.09 \\
\hline 72 & Achromobacter xylosoxydans & KM 583 & B & 69.5 & 59 & 0.05 & 60 & 0.06 \\
\hline 73 & Alcaligenes faecalis & $\mathrm{AB} 1286$ & A & 57.2 & 56.5 & 0.04 & 58 & 0.12 \\
\hline 74 & Alcaligenes odorans & Gilardi 117 & A & 57.9 & 57 & 0.06 & 58 & 0.08 \\
\hline 75 & "Alcaligenes" paradoxus & ATCC 17712 & $\mathbf{B}$ & 67.9 & 61 & 0.05 & & \\
\hline 76 & Escherichia coli & B & $\mathbf{R}$ & 52.2 & 62.5 & 0.11 & & \\
\hline 77 & $\begin{array}{l}\text { Enterobacter aerogenes } \\
\text { Enterobacter agglomerans }\end{array}$ & NCTC 10006 & $J$ & 53.8 & 63 & 0.11 & & \\
\hline 78 & $\begin{array}{l}\text { ("Agrobacterium gypsophi- } \\
\text { lae") }\end{array}$ & IPO 445 & B & 60.6 & 62 & 0.12 & & \\
\hline 79 & $\begin{array}{l}\text { ("Agrobacterium gypsophi- } \\
\text { lae") }\end{array}$ & ATCC 13329 & B & 56.2 & 63.5 & 0.12 & & \\
\hline 80 & $\begin{array}{l}\text { ("Agrobacterium gypsophi- } \\
\text { lae") }\end{array}$ & IPO $280 \mathrm{e}$ & B & 55.7 & 63.5 & 0.12 & & \\
\hline 81 & Erwinia amylovora & NCPPB 683 & B & 54.0 & 61.5 & 0.12 & 60.5 & 0.17 \\
\hline 82 & Erwinia lathyri & PA & B & 56.5 & & & 60 & 0.17 \\
\hline 83 & Klebsiella pneumoniae & N4B & $\mathbf{J}$ & 58.6 & 62 & 0.10 & 62 & 0.15 \\
\hline 84 & Salmonella typhimurium & 1 & B & 55.2 & 62 & 0.11 & & \\
\hline 85 & Salmonella pullorum & 3 & W & 54.0 & & & 61 & 0.15 \\
\hline 86 & Aeromonas formicans & NCIB 9232 & $\mathbf{F}$ & 64.8 & 60 & 0.13 & & \\
\hline 87 & Aeromonas salmonicida & NCMB 833 & G & 57.0 & 59 & 0.13 & & \\
\hline 88 & Pseudomonas diminuta & CCEB 513 & B & 67.3 & 65 & 0.06 & & \\
\hline 89 & Pseudomonas aeruginosa & NCTC 7244 & B & 66.8 & 62.5 & 0.06 & & \\
\hline 90 & Pseudomonas aureofaciens & CCEB 518 & $\mathbf{B}$ & 62.8 & 59.5 & 0.08 & & \\
\hline 91 & Pseudomonas cichorii & NCPPB 906 & B & 59.7 & 61.5 & 0.11 & 60 & 0.10 \\
\hline 92 & Pseudomonas coronafaciens & NCPPB 1328 & $\mathrm{~L}$ & 59.3 & 62.5 & 0.08 & & \\
\hline 93 & Azotobacter paspali & 22B & $\mathbf{M}$ & 63.7 & 59.5 & 0.09 & & \\
\hline 94 & Azotobacter vinelandii & NCIB 8660 & $\mathrm{~K}$ & 65.0 & 62 & 0.07 & & \\
\hline 95 & Azomonas macrocytogenes & NCIB 8200 & $\mathrm{~K}$ & 58.6 & 61.5 & 0.07 & & \\
\hline 96 & Azomonas agilis & SS4 & $\mathbf{H}$ & 52.8 & 63.5 & 0.08 & & \\
\hline 97 & Bordetella bronchiseptica & ATCC 10580 & B & 68.2 & 58.5 & 0.06 & & \\
\hline 98 & Bordetella bronchiseptica & NCTC 8761 & $\mathbf{B}$ & 69.5 & 60 & 0.06 & & \\
\hline 99 & $\begin{array}{l}\text { Campylobacter fetus subsp. } \\
\text { jejuni }\end{array}$ & M2 & & 34.0 & 57 & 0.07 & & \\
\hline 100 & Arthrobacter oxydans & CBRI 21010 & $\mathrm{O}$ & 62.4 & 56 & 0.07 & 59.5 & 0.12 \\
\hline 101 & $\begin{array}{l}\text { Arthrobacter polychromo- } \\
\text { genes }\end{array}$ & CBRI 21038 & $\mathrm{O}$ & 60.8 & 57 & 0.07 & 57 & 0.09 \\
\hline 102 & Arthrobacter sp. & CBRI ER39 & $\mathrm{O}$ & 65.1 & 55 & 0.09 & 56.5 & 0.11 \\
\hline 103 & Arthrobacter sp. & CBRI ER56 & $\mathrm{O}$ & 63.2 & 55.5 & 0.07 & 56 & 0.10 \\
\hline 104 & Arthrobacter globiformis & CBRI 21033 & $\mathrm{O}$ & 66.0 & 59 & 0.09 & 55 & 0.14 \\
\hline 105 & Arthrobacter aurescens & CBRI 21002 & $\mathrm{O}$ & 59.5 & 57 & 0.11 & 55 & 0.18 \\
\hline 106 & Arthrobacter oxydans & CBRI 21011 & $\mathrm{O}$ & 65.9 & 55.5 & 0.09 & 57 & 0.14 \\
\hline 107 & $\begin{array}{l}\text { Arthrobacter histidinolovor- } \\
\text { ans }\end{array}$ & CBRI 21040 & $\mathrm{O}$ & 61.3 & 57 & 0.10 & 55.5 & 0.12 \\
\hline 108 & Arthrobacter sp. & CBRI ER2 & $\mathbf{0}$ & 60.5 & 56 & 0.07 & 58 & 0.11 \\
\hline 109 & Arthrobacter sp. & CBRI ER3 & 0 & 61.0 & 56 & 0.07 & 56 & 0.10 \\
\hline 110 & Arthrobacter tumescens & CBRI 21016 & $\mathbf{Q}$ & 72.4 & 55 & 0.06 & 57 & 0.08 \\
\hline 111 & Arthrobacter crystallopoites & CBRI 21030 & $\mathrm{O}$ & 63.9 & 57 & 0.15 & 56.5 & 0.15 \\
\hline 112 & Arthrobacter atrocyaneus & CBRI 21001 & $\mathrm{O}$ & 70.5 & 57 & 0.08 & 59 & 0.10 \\
\hline 113 & Arthrobacter flavescens & CBRI 21005 & $\mathrm{P}$ & 70.3 & 58 & 0.06 & 58 & 0.06 \\
\hline
\end{tabular}


TABLE 1-Continued

\begin{tabular}{|c|c|c|c|c|c|c|c|c|}
\hline \multirow{3}{*}{$\begin{array}{l}\text { No. in } \\
\text { Fig. } 3 \\
\text { or } 4\end{array}$} & \multirow{3}{*}{$\begin{array}{l}\text { Organism used for } \\
\text { DNA prepn }\end{array}$} & \multirow{3}{*}{$\begin{array}{l}\text { Origin and } \\
\text { strain no. }\end{array}$} & \multirow{3}{*}{$\begin{array}{l}\text { Growth } \\
\text { medium }^{a}\end{array}$} & \multirow{3}{*}{$\begin{array}{l}\mathrm{Mol} \% \\
\mathrm{G}+\mathrm{C}^{b}\end{array}$} & \multicolumn{4}{|c|}{ Hybridization with rRNA from: } \\
\hline & & & & & \multicolumn{2}{|c|}{$\begin{array}{c}\text { Agrobacterium } \\
\text { tumefaciens } \\
\text { TT111 }\end{array}$} & \multicolumn{2}{|c|}{$\begin{array}{l}\text { Agrobacterium } \\
\text { rhizogenes } \\
\text { TR7 }\end{array}$} \\
\hline & & & & & $T_{m(e)}$ & $\begin{array}{l}\% \text { bind- } \\
\text { ing }\end{array}$ & $T_{m(e)}$ & $\begin{array}{l}\text { \% bind- } \\
\text { ing }\end{array}$ \\
\hline 114 & $\begin{array}{l}\text { "Agrobacterium" pseudotsu- } \\
\text { gae }\end{array}$ & ATCC 13330 & $\mathbf{A}$ & & 57 & 0.10 & & \\
\hline 115 & $\begin{array}{l}\text { "Agrobacterium" pseudotsu- } \\
\text { gae }\end{array}$ & NCPPB 180 & $\mathbf{A}$ & 67.7 & 56.5 & 0.12 & & \\
\hline 116 & Corynebacterium glutamicum & MPS 10 & B & 54.5 & & & 57 & 0.15 \\
\hline 117 & Corynebacterium insidiosum & Joubert A & B & & 55 & 0.04 & & \\
\hline 118 & Corynebacterium fascians & D 188 & B & & 54.5 & 0.05 & & \\
\hline 119 & Microbacterium flavum & NCIB 8707 & B & 58.2 & 59 & 0.08 & & \\
\hline 120 & Microbacterium lacticum & NCIB 8540 & $\mathbf{S}$ & 62.9 & 57 & 0.02 & & \\
\hline 121 & Nocardia asteroides & IMET 7020 & $\mathbf{B}$ & & 58.5 & 0.04 & & \\
\hline 122 & Nocardia turbata & n 32 & B & & 58 & 0.08 & & \\
\hline 123 & Mycobacterium rhodochrous & 01 & B & & 58 & 0.05 & & \\
\hline 124 & Bacillus megaterium & 899 thy $^{-}$ & B & 39.9 & 60 & 0.19 & & \\
\hline 125 & Bacillus pumilus & B 12 & B & 42.7 & 58 & 0.10 & & \\
\hline 126 & Bacillus subtilis & BQ 2 & B & 47.7 & 59 & 0.16 & & \\
\hline 127 & HeLa & & & 40.0 & & 0 & & \\
\hline
\end{tabular}

a For composition of the growth media, see Table 2.

b The moles percent guanine plus cytosine $(\mathrm{G}+\mathrm{C})$ values were determined in our laboratory on previous occasions by thermal denaturation.

containing solvent in 3-degree temperature steps from 62 to $86^{\circ} \mathrm{C}$. Radioactivity released at each temperature step was counted as above, but in Bray solution (6).

\section{RESULTS}

16S and 23S rRNA fractions. Although 23S rRNA is frequently nicked (62), it can readily be prepared intact from many bacteria. Agrobacterium represents an extreme case: almost no $23 \mathrm{~S}$ RNA can be prepared from it $(20,32,47$, 48), because it contains at least two nicks (33, 62). When ${ }^{14} \mathrm{C}$-labeled rRNA from our reference strains A. tumefaciens TT111, A. rhizogenes TR7, and Escherichia coli B were separated on a sucrose gradient, and the distributions were aligned on the $16 \mathrm{~S}$ peaks, it appeared that the agrobacterial $23 \mathrm{~S}$ peaks were lighter and much smaller than the 23S E. coli peak (Fig. 1). Even when rRNA was prepared in the presence of either bentonite (52), or $2 \%$ sodium lauryl sulfate (55), the yield of the 23S fraction remained low. In view of Schuch's and Loening's (62) results, our agrobacterial $23 \mathrm{~S}$ peaks consisted most likely of RNA with a molecular weight of $0.95 \times 10^{6}$, and the $16 \mathrm{~S}$ peaks were probably heavily contaminated with fragmented 23S. For the sake of simplicity we shall continue to use both symbols. There is no evidence that the 23S fraction would be contaminated by $16 \mathrm{~S}$.

Similarity between $16 \mathrm{~S}$ and $23 \mathrm{~S}$ rRNA and the number of rRNA cistrons in Agrobacter- ium. We saturated filter-fixed DNA from both Agrobacterium reference strains with 16S, 23S, or the mixed preparation of homologous ${ }^{14} \mathrm{C}$ labeled rRNA (for method, see 20). The percentage of rRNA binding in the case of A. tumefaciens was 0.189 and in the case of A. rhizogenes it was 0.154 and 0.150 (Table 3 ). These results suggested that the base sequences in $16 \mathrm{~S}$ and $23 \mathrm{~S}$ rRNA cistrons in each strain were very similar.

Table 3 shows that the A. tumefaciens TT111 DNA genome probably contains a total length of rRNA cistrons equivalent to $1216 \mathrm{~S}$ units. Saturation hybridization indicates an equivalent of $10 \mathrm{16S}$ units in A. rhizogenes. Crosshybridization (Table 1, Fig. 3 and 4) confirmed this conclusion. When ${ }^{14} \mathrm{C}$-labeled rRNA from either A. tumefaciens TT111 or A. rhizogenes TR7 were hybridized to DNA from strains of both cluster 1 and cluster $2(16,17)$, the percentage of rRNA binding was on the average $25 \%$ smaller with the latter, confirming that bacteria from the rhizogenes cluster 2 have fewer rRNA cistrons per genome.

Stability of hybrids and 16S and 23S rRNA fractions. Table 4 compares the thermal stability of a number of rDNA hybrids with either $16 \mathrm{~S}$ or $23 \mathrm{~S}{ }^{14} \mathrm{C}$-labeled $\mathrm{rRNA}$ from $A$. tumefaciens TT111. From the 11 pairs of determinations, it followed that the stability of both types of hybrids usually differs by at most $1^{\circ} \mathrm{C}$. When the percentage of rRNA binding drops to 0.05 to 0.06 and below, there may be 2 to $3^{\circ} \mathrm{C}$ differ- 


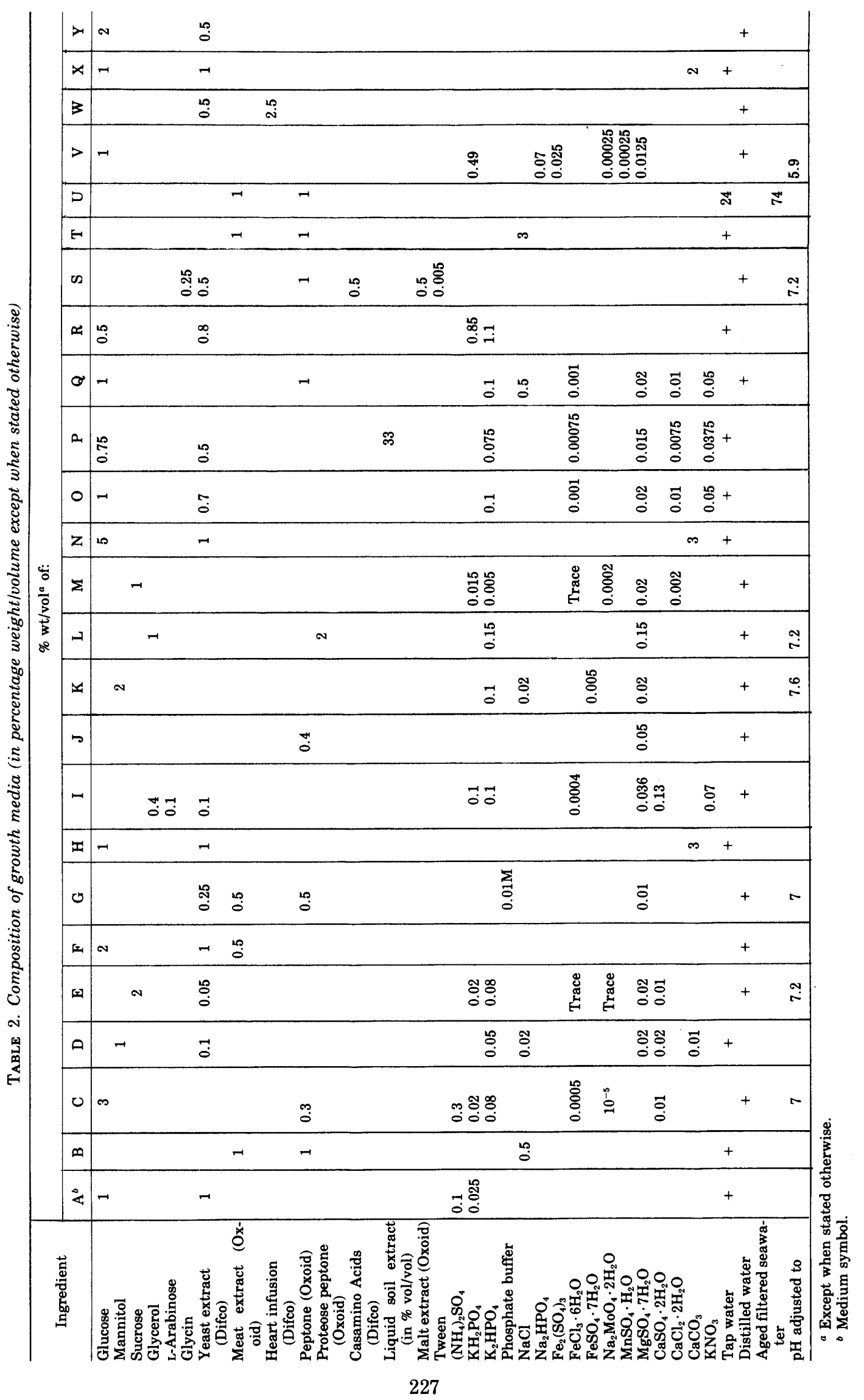


ence, largely because of experimental errors. The percentage of rRNA binding was also very similar with either $16 \mathrm{~S}$ or $23 \mathrm{~S}$ rRNA; the difference was usually at most $0.02 \%$.

Comparison of the rRNA hybrids. Ribosomal RNA similarity was expressed by two parameters, $T_{m(e)}$ and percent rRNA binding. The latter value depended not only on the actual rRNA homology, but also on the size of the genome, its state of replication, and the number of rRNA cistrons per genome; it represented a certain amount of rRNA bound, typical for each taxon, but it can by no means be called rRNA homology. We determined a great variety of melting curves, combinations of high and
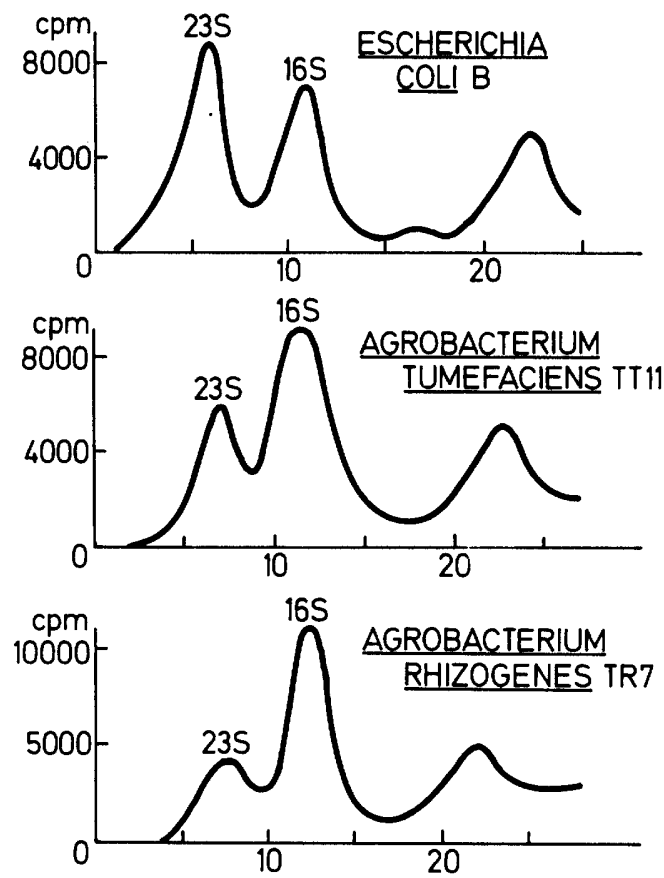

FIG. 1. ${ }^{14}$ C-labeled $r R N A$ distributions in a linear 15 to $30 \%$ sucrose gradient. low $T_{m(e)}$ values, high and low percent RNA binding values, and values in between. A few examples are given in Fig. 2. All parameters are compiled in Table 1 . The correlations between the data were better revealed by plotting, for each labeled reference rRNA, $T_{m(e)}$ versus percent rRNA binding. The resulting graphs (Fig. 3 and 4) were called here rRNA similarity maps. A few reciprocal hybridizations between DNA from Agrobacterium and ${ }^{14} \mathrm{C}$-labeled rRNA from various other genera are shown in Table 5.

Amount and stability of DNA:DNA hybrids. A number of DNA:rRNA hybridizations suggested definite relationships between strains and taxa, which were hitherto unknown (see Discussion). We examined their overall genome similarity with Agrobacterium by DNA:DNA hybridizations. We included a large number of control strains, several of them phytopathogens (Table 6). When the melting curves of all of these duplexes were examined, they could be separated arbitrarily into five types (Fig. 5). First there were the homologous DNA:DNA duplexes (for example, TT111 $\times{ }^{14} \mathrm{C}$-labeled TT111 or B6 $\times{ }^{14} \mathrm{C}$-labeled B6; type I) and the heterologous duplexes between representatives of the genetic groups within cluster 1 (type II); they were included as controls. Earlier we reported extensively on the nature of the DNA:DNA duplexes within Agrobacterium (25). Type III melting curves were from strains which displayed a distinct genome similarity with Agrobacterium, such as several rhizobia, Mycoplana, "Achromobacter" hartlebii, and Azotomonas fluorescens (see Table 6). Type IV melting curves were from strains which displayed a weak to very weak but still distinct genome similarity with Agrobacterium, such as some remote rhizobia, Phyllobacterium, the strains AB 940, AB 1196, and AB 1293, etc. All of the other strains formed no DNA:DNA complexes with Agrobacterium (type V).

TABLE 3. Estimation of the number of rRNA cistrons in Agrobacterium ${ }^{a}$

\begin{tabular}{|c|c|c|c|c|c|}
\hline $\begin{array}{l}{ }^{14} \mathrm{C} \text {-labeled } \\
\text { rRNA from: }\end{array}$ & $\begin{array}{c}\text { Mol wt of genome } \\
\text { DNA }\end{array}$ & $\begin{array}{c}{ }^{14} \mathrm{C} \text {-labeled rRNA } \\
\text { prepn }\end{array}$ & $\begin{array}{l}\% \text { rRNA bind- } \\
\text { ing }\end{array}$ & $\begin{array}{l}\text { Total mol wt of } \\
\text { rRNA bound per } \\
\text { DNA genome }\end{array}$ & $\begin{array}{l}\text { Total no. of } \\
\text { rRNA cistrons } \\
\text { per DNA ge- } \\
\text { nome ex- } \\
\text { pressed as } 16 \mathrm{~S} \\
\text { units }\end{array}$ \\
\hline $\begin{array}{l}\text { A. tumefaciens } \\
\text { ICPB TT111 }\end{array}$ & $3.4 \times 10^{9}$ & $\begin{array}{c}16 S \\
23 S \\
16 S+23 S\end{array}$ & $\begin{array}{l}0.189 \\
0.189 \\
0.189\end{array}$ & $\begin{array}{l}6.43 \times 10^{6} \\
6.43 \times 10^{6} \\
6.43 \times 10^{6}\end{array}$ & 12 \\
\hline $\begin{array}{l}\text { A. rhizogenes } \\
\text { ICPB TR7 }\end{array}$ & $3.6 \times 10^{9}$ & $\begin{array}{l}16 \mathrm{~S} \\
23 \mathrm{~S}\end{array}$ & $\begin{array}{l}0.154 \\
0.150\end{array}$ & $\begin{array}{r}5.54 \times 10^{6} \\
5.4 \times 10^{6}\end{array}$ & 10 \\
\hline
\end{tabular}

a The molecular weight of the genome DNA was determined with the initial renaturation rate method (28). 
TABLE 4. Comparison of the stability of hybrids with either $16 S$ or $23 S{ }^{14} \mathrm{C}$-labeled rRNA from Agrobacterium tumefaciens ICPB TT111 ${ }^{a}$

\begin{tabular}{lllllc}
\hline \multicolumn{1}{c}{ DNA from: } & \multicolumn{2}{c}{$16 \mathrm{~S}$} & & \multicolumn{2}{c}{$23 \mathrm{~S}$} \\
\cline { 2 - 5 } \cline { 4 - 6 } & $T_{m(e)}$ & $\%$ & $T_{m(e)}$ & $\%$ \\
\hline Agrobacterium tumefaciens ICPB TT111 & 81 & 0.19 & & 81 & 0.19 \\
Agrobacterium sp. 4.1 & 81 & 0.14 & & 81 & 0.13 \\
Agrobacterium rhizogenes ICPB TR7 & 78 & 0.12 & & 77.5 & 0.10 \\
Rhizobium meliloti USDA 3D0a30 & 77 & 0.10 & & 78 & 0.08 \\
Rhizobium leguminosarum USDA 316C10A & 76 & 0.08 & & 77 & 0.09 \\
Rhizobium leguminosarum 11.1 & 77 & 0.12 & & 77.5 & 0.10 \\
Rhizobium leguminosarum 5.0 & 76 & 0.11 & & 77 & 0.09 \\
Rhizobium leguminosarum USDA 3F3C1 & 71 & 0.06 & & 74 & 0.06 \\
Rhizobium leguminosarum USDA 3F6g2 & 72.5 & 0.06 & & 75 & 0.05 \\
Arthrobacter polychromogenes CBRI 21038 & 57 & 0.07 & & 54 & 0.07 \\
Arthrobacter oxydans CBRI 21011 & 55.5 & 0.09 & & 53.5 & 0.09 \\
\hline
\end{tabular}

${ }^{a}$ The results are expressed in percent rRNA binding and as $T_{m(e)}$ of the hybrids in ${ }^{\circ} \mathrm{C}$.

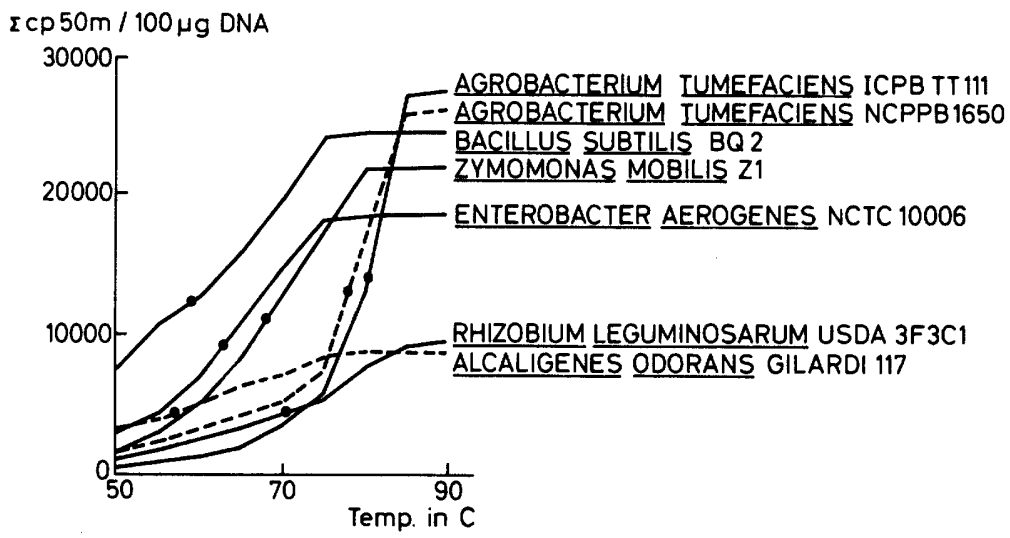

Fig. 2. Examples of melting curves of hybrids between $16 S{ }^{14} \mathrm{C}$-labeled rRNA from Agrobacterium tumefaciens TT111 and filter-fixed DNA from various bacteria. The total amount of cp50m/100 $\mu \mathrm{g}$ of DNA (counts per 50 min per $100 \mu \mathrm{g}$ of filter-fixed DNA) is a measure of the amount of hybrid denatured. The melting point $T_{m(e)}$ is represented by the central dot on each curve.

\section{DISCUSSION}

When the results were plotted in an rRNA similarity map, each strain had a fixed position (within the limits of reproducibility, $T_{m(e)}$ $\pm 0.5^{\circ} \mathrm{C}$; percent rRNA binding $\pm 0.015 \%$ ). Strains of the same species, which are phenotypically and genotypically very similar, are almost indistinguishably together on the map. Examples are the four strains of Phyllobacterium myrsinacearum (numbers 51 to 54), three strains of Enterobacter agglomerans (numbers 78,79 , and 80), and both strains of Chromobacterium lividum (numbers 62 and 63). Species from the same genus are close together within a limited area. In several cases, only a small number of strains were included merely to locate the position of the genus on the map, not its area shape. When more strains are used, the shape and size of the area occupied by a genus is a measure of its heterogeneity. From previous research in this laboratory $(16,17,25,42)$ we know that Agrobacterium is a rather heterogeneous genus, consisting of two large genetic clusters, 1 (exemplified by Agrobacterium radiobacter and $A$. tumefaciens strains, numbers 1 to 15 ) and 2 (exemplified by the rhizogenic and atypical $A$. tumefaciens strains, numbers 16 to 19), a small Agrobacterium rubi cluster (numbers 20 and 21), and a few isolated strains (numbers 22, 23, and 24). These clusters hybridize at about $15 \%$ DNA homology among each other. Cluster 1 consists of seven genetic races called TT111 (numbers 1, 5, and 11), B6 (numbers $2,3,4,10,15$ ), TT9 (numbers 6,7 , and 13 ), $3 / 1$ (number 8), F/1 (number 9), 0362 (number 12), and M2/1 (number 14). These seven genetic races hybridize among each other with 45 to 50\% DNA homology. Both clusters 1 and 2 occupy separate areas on our maps (Fig. 3 and 4). 

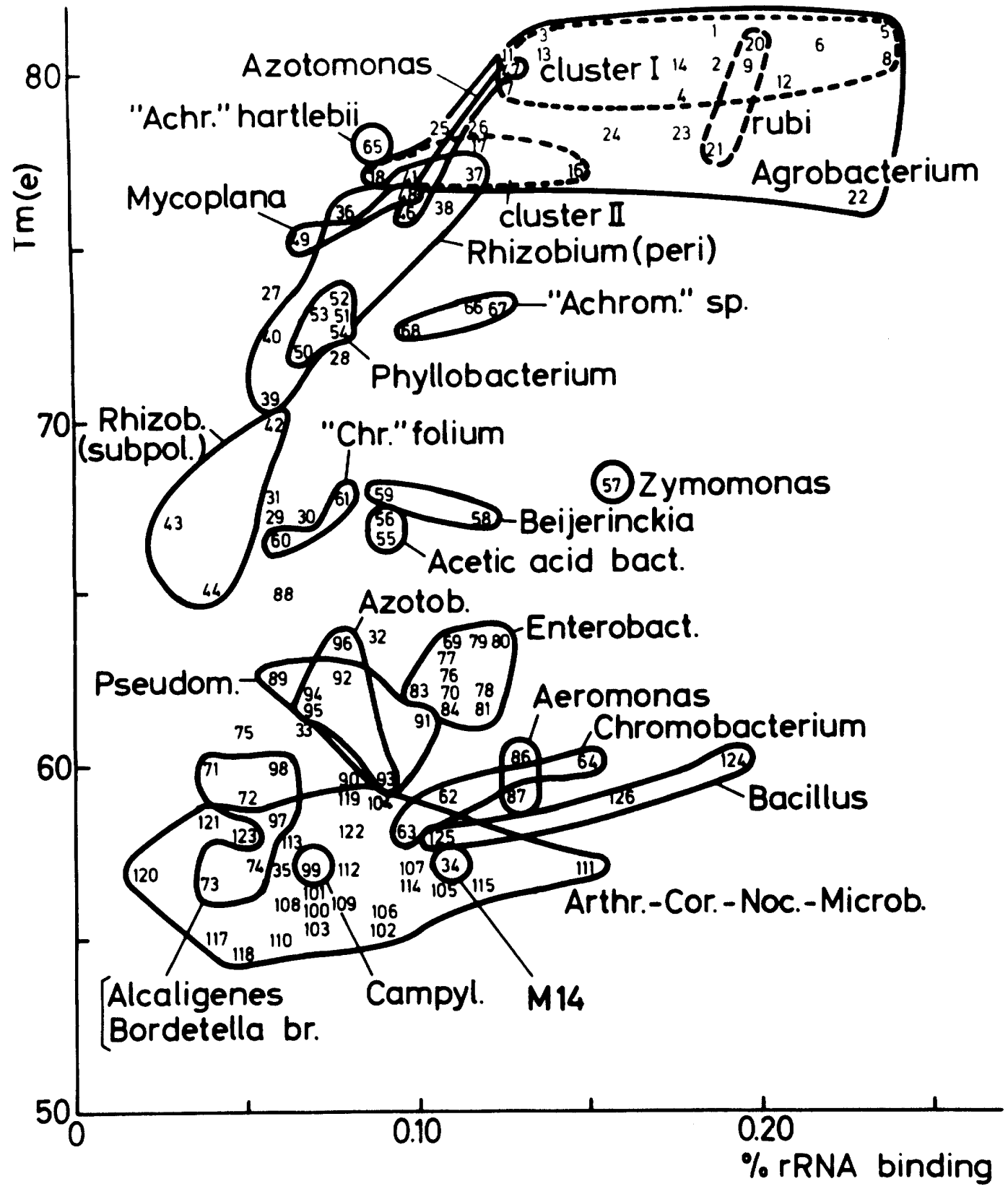

FIG. 3. Similarity map of hybrids between the $16 S{ }^{14} \mathrm{C}$-labeled rRNA fraction of Agrobacterium tumefaciens ICPB TT111 and DNA from a variety of bacteria. $T_{m(e)}$ and $\%$ rRNA binding are as defined in the text. To simplify the drawing each strain is represented by a sequence number (Table 1), which is not the strain number. The positions of all strains, belonging phenotypically to the same taxon (usually a genus), are surrounded by a closed line. These areas locate the taxa on the map; their shapes and dimensions are limited by the numbers of strains used; the line is not the ultimate border.

The genetically separate strains $A$. tumefaciens NCPPB 1771 (number 22), NCPPB 1650 (number 23), and NCPPB 930 (number 24) are outside the areas occupied by cluster 1 or 2 . In
1973 a severe outbreak of cane gall occurred on red raspberries in Scotland, occasioned by Agrobacterium sp. (M. Pérombelon, personal communication). These strains (numbers 25 

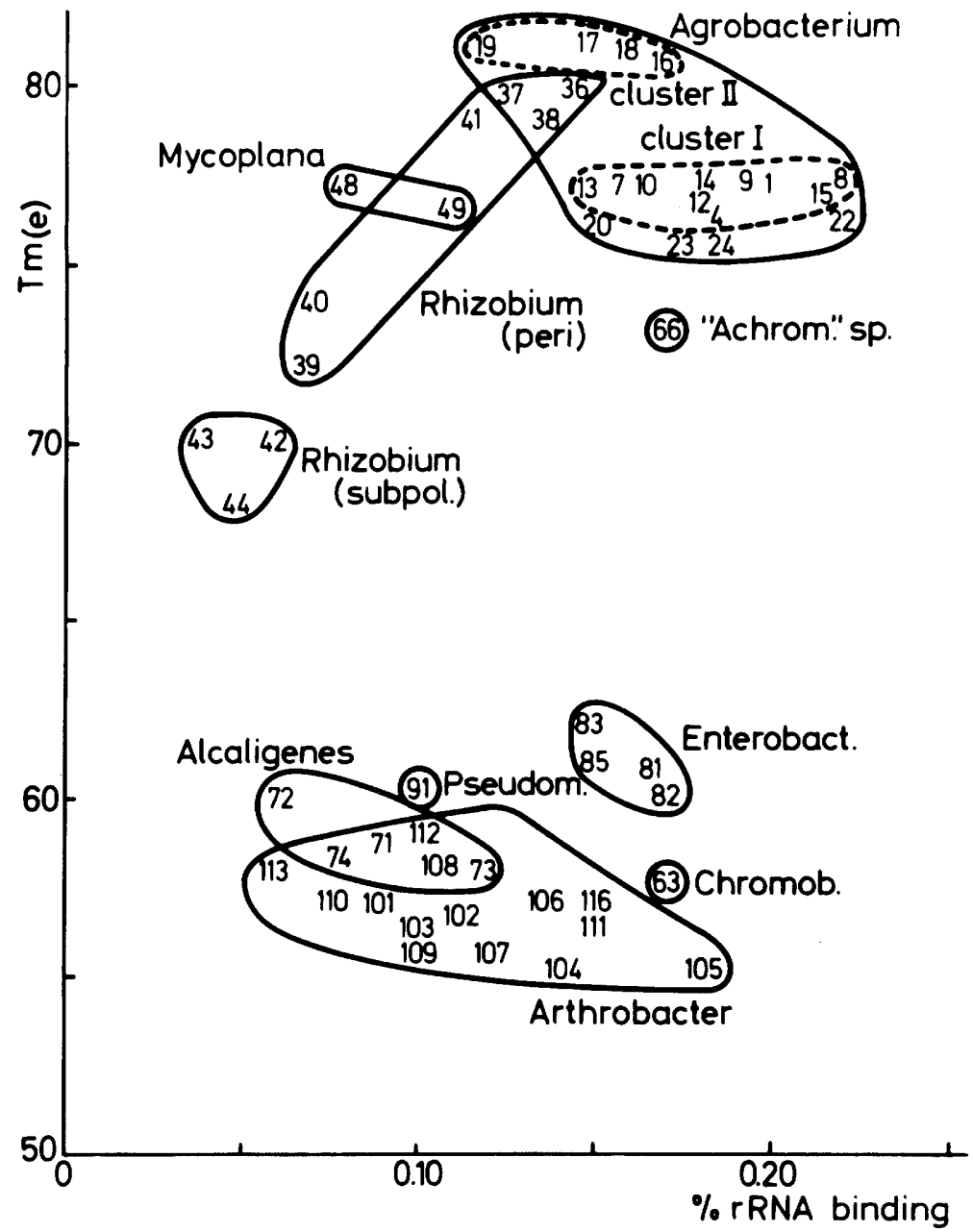

FIG. 4. Similarity map of hybrids between the $16 S{ }^{14} \mathrm{C}$-labeled rRNA fraction of Agrobacterium rhizogenes ICPB TR7 and DNA from a variety of bacteria. For further details, see legend to Fig. 3.

and 26) are phenotypically rather separate, fitting in none of our genetic races ( $K$. Kersters and J. De Ley, unpublished data). The rRNA hybridization data confirmed that they are agrobacteria.

The rhizobia consist of two main subgroups: the fast-growing peritrichously flagellated organisms and the slow-growing subpolarly flagellated group $(9,23,29)$. Representative strains of each subgroup were included. The peritrichous subgroup (strains 36 to 41 ) is probably very heterogeneous. DNA:DNA hybridizations below the optimal renaturation temperature allow more mismatchings and are thus able to detect more remote relationships. In this fashion Heberlein et al. (35) found that the fastgrowing rhizobia have definite genetic similarities with cluster 2 of Agrobacterium and that the slow-growing rhizobia are separate. Our present results point definitely in the same direction. The similarity area of the rRNA cistrons of peritrichously flagellated Rhizobium strains borders on and even overlaps with the area of cluster 2 (Fig. 3 and 4). The rRNA cistrons of the slow-growing rhizobia (numbers 42, 43, and 44) are much less similar.

Is there a correlation between the rRNA similarities and other features of the genera examined? We were unable to correlate the percentage of rRNA binding with phenotypic features of the genera examined. For example, Agrobacterium has percent rRNA binding values in the same range as the Enterobacteriaceae, Chromobacterium, Bacillus, and some Arthrobacter species. There are but limited phenotypical similarities between these taxa. However, 


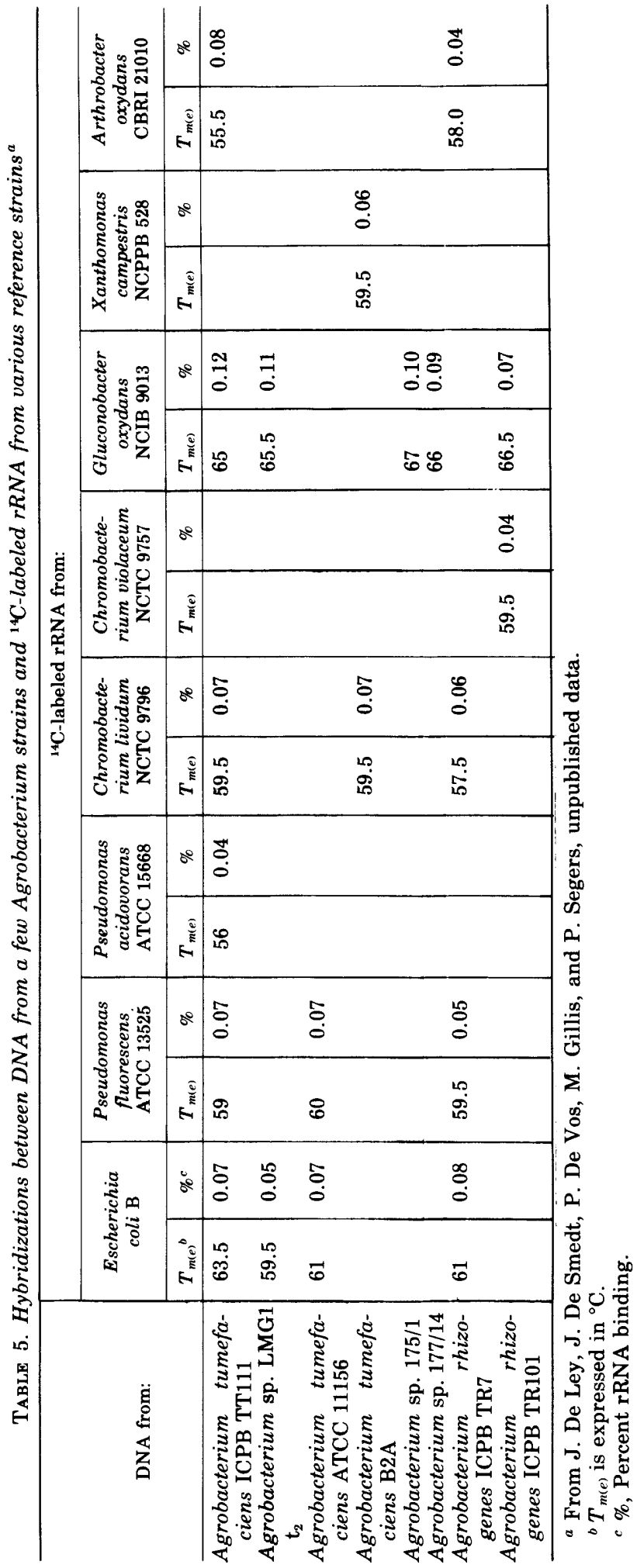


TABLE 6. Amount and thermal stability of stable DNA:DNA duplexes between two reference Agrobacterium strains and several other organisms ${ }^{a}$

\begin{tabular}{|c|c|c|c|c|c|c|}
\hline \multirow[b]{2}{*}{ Organism } & \multicolumn{2}{|c|}{$\begin{array}{c}\text { A. tumefaciens } \\
\text { TT111 }{ }^{14} \mathrm{C}-\text { labeled } \\
\text { DNA }\end{array}$} & \multicolumn{2}{|c|}{$\begin{array}{l}\text { A. tumefaciens B6 } \\
{ }^{14} \text { C-labeled DNA }\end{array}$} & \multicolumn{2}{|c|}{$\begin{array}{l}\text { Type of melting } \\
\text { curve (see Fig. } \\
\text { 5) }\end{array}$} \\
\hline & $\begin{array}{c}\%{ }^{14} \mathrm{C}-\mathrm{la}- \\
\text { beled DNA } \\
\text { bound vs. } \\
\text { homolo- } \\
\text { gous DNA }\end{array}$ & $T_{m(e)^{b}}^{b}$ & $\begin{array}{c}\%{ }^{14} \mathrm{C}-\mathrm{la}- \\
\text { beled DNA } \\
\text { bound vs. } \\
\text { homolo- } \\
\text { gous DNA }\end{array}$ & $T_{m(e)}$ & curve & Fig. \\
\hline Agrobacterium tumefaciens ICPB TT111 & $(100)$ & 75.3 & 58 & 68.4 & I & II \\
\hline Agrobacterium tumefaciens $\mathrm{B} 6$ & 51 & 69.5 & $(100)$ & 75.4 & II & I \\
\hline Agrobacterium tumefaciens IPO 417 & 84 & 75.3 & & & I & \\
\hline Agrobacterium rhizogenes ICPB TR101 & 6 & Low $^{c}$ & 11 & Low & IV & \\
\hline Agrobacterium tumefaciens NCPPB 1649 & 6 & 63.2 & 11 & Low & IV & \\
\hline Azotomonas insolita NCIB 9749 & & & 45 & 68.4 & II & \\
\hline Azotomonas fluorescens NCIB 9884 & & & 7 & 64.9 & III & \\
\hline $\begin{array}{l}\text { Rhizobium leguminosarum USDA } \\
\text { 316C10A }\end{array}$ & 11 & 65.0 & & & III & \\
\hline $\begin{array}{l}\text { Rhizobium leguminosarum USDA } \\
\text { 3F3C1 }\end{array}$ & 6 & 63 & & & IV & \\
\hline Rhizobium meliloti 1.5 & 11 & 64.3 & & & III & \\
\hline Rhizobium meliloti USDA 3D0a30 & 6 & 63.8 & & & IV & \\
\hline Rhizobium japonicum USDA 3I1b59 & 3 & Low & & & $\mathrm{V}$ & \\
\hline Rhizobium japonicum 3.2 & 6 & Low & & & V & \\
\hline Mycoplana bullata NCIB 9440 & 9 & 64.8 & & & III & \\
\hline Mycoplana dimorpha NCIB 9439 & 10 & 65 & & & III & \\
\hline "Achromobacter" hartlebii NCIB 8129 & 11 & 63.7 & 12 & 64.8 & III & \\
\hline "Achromobacter" sp. AB 1196 & 6 & 63.1 & & & IV & \\
\hline "Achromobacter" sp. AB 1293 & 7 & 63.1 & & & IV & \\
\hline "Alcaligenes" sp. AB 940 & 7 & 62.8 & 5 & 64.1 & IV & \\
\hline Phyllobacterium myrsinacearum $\mathrm{LMG}_{2} \mathrm{t}_{1}$ & & & 7 & 63.9 & IV & \\
\hline Phyllobacterium myrsinacearum $\mathrm{LMG}_{2} \mathrm{t}_{2}$ & & & 6 & 63.6 & IV & \\
\hline Phyllobacterium myrsinacearum $\mathrm{LMG}_{3} \mathrm{t}_{1}$ & & & 4 & 64 & IV & \\
\hline Phyllobacterium myrsinacearum $\mathrm{LMG}_{3} \mathrm{t}_{2}$ & & & 6 & 64.3 & IV & \\
\hline Phyllobacterium rubiacearum $\mathrm{LMG}_{1} \mathrm{t}_{1}$ & & & 4 & 64 & IV & \\
\hline $\begin{array}{l}\text { "Chromobacterium lividum" NCTC } \\
10590\end{array}$ & & & 2 & 63 & $\mathrm{~V}$ & \\
\hline $\begin{array}{l}\text { "Chromobacterium lividum" NCTC } \\
10591\end{array}$ & & & 2 & 63.4 & $\mathrm{~V}$ & \\
\hline "Agrobacterium gypsophilae" IPO 280e & & & 1 & 62.8 & $\mathrm{~V}$ & \\
\hline "Agrobacterium azotophilum" (Ulloa) & & & 1 & 63 & V & \\
\hline "Agrobacterium" sp. Sundman $08=113$ & & & 1 & 63 & V & \\
\hline Acetobacter aceti subsp. aceti $\mathrm{Ch} 31$ & 2 & Low & & & $\mathrm{V}$ & \\
\hline $\begin{array}{l}\text { Acetobacter pasteurianus subsp. estunen- } \\
\text { sis E }\end{array}$ & 2 & Low & & & V & \\
\hline Alcaligenes faecalis $\mathrm{AB} 1286$ & 3 & Low & & & $\mathrm{V}$ & \\
\hline Alcaligenes odorans Gilardi 117 & 3 & Low & & & V & \\
\hline Achromobacter denitrificans M250 & 4 & Low & & & $\mathrm{V}$ & \\
\hline Pseudomonas aureofaciens CCEB 518 & 3 & Low & & & $\mathrm{V}$ & \\
\hline Pseudomonas cichorii NCPPB 906 & 4 & Low & & & V & \\
\hline $\begin{array}{l}\text { Pseudomonas coronafaciens NCPPB } \\
1328\end{array}$ & 2 & Low & & & $\mathrm{V}$ & \\
\hline Salmonella typhimurium 1 & 3 & Low & & & $\mathrm{V}$ & \\
\hline Erwinia lathyri PA & 3 & Low & & & $\mathrm{V}$ & \\
\hline Klebsiella pneumoniae N4B & 2 & Low & & & $\mathrm{V}$ & \\
\hline Klebsiella rubiacearum & 3 & Low & & & $\mathrm{V}$ & \\
\hline
\end{tabular}

a Part of the data are from De Ley and Tytgat.

${ }^{b} T_{m(e)}$ is expressed in ${ }^{\circ} \mathrm{C}$.

$c$ "Low" refers to a weakly stable molecular hybrid with $T_{m(e)}<62^{\circ} \mathrm{C}$. 

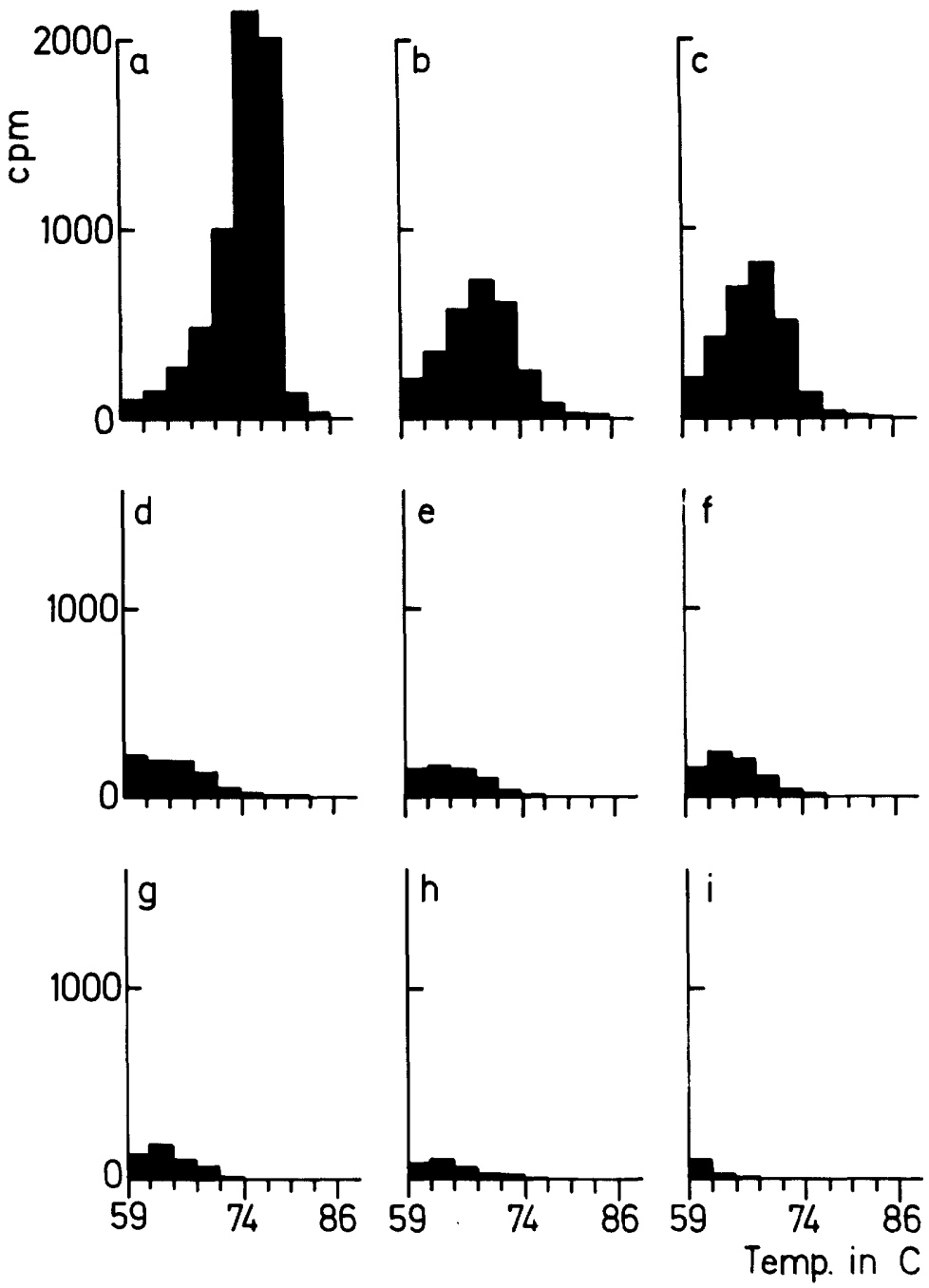

Fig. 5. Typical differential denaturation curves of duplexes between ${ }^{14} \mathrm{C}$-labeled DNA from either strain Agrobacterium tumefaciens TT111 or B6, with a number of heterologous DNAs. The type of melting curve (see Fig. 5) is given in parentheses. (a) Homologous control: ${ }^{14} \mathrm{C}$-labeled DNA from A. tumefaciens B6 $\times$ DNA from A. tumefaciens B6 (type I). (b) Heterologous control: ${ }^{14} \mathrm{C}$-labeled DNA from A. tumefaciens TT111 $\times$ DNA from A. radiobacter ATCC 4718 (B6 group) (type II). (c) ${ }^{14} \mathrm{C}$-labeled DNA from A. tumefaciens B6 $\times$ DNA from the misnamed strain "Azotomonas insolita" NCIB 9749 (type II). (d) ${ }^{14} C$-labeled DNA from A. tumefaciens TT111 $\times$ DNA from Rhizobium leguminosarum 316C10a (type III). (e) ${ }^{14} \mathrm{C}$-labeled DNA from A. tumefaciens TT111 $\times$ DNA from Mycoplana bullata NCIB 9440 (type III). (f) ${ }^{14}$ C-labeled DNA from A. tumefaciens B6 $\times$ DNA from "Achromobacter" hartlebii NCIB 8129 (type III). (g) ${ }^{14}$ C-labeled DNA from A. tumefaciens $B 6 \times D N A$ from Phyllobacterium myrsinacearum $L M G_{2} t_{1}\left(\right.$ type IV). $(h){ }^{14}$ C-labeled DNA from A. tumefaciens B6 $\times$ DNA from "Alcaligenes" AB 940 (type IV). (i) ${ }^{14}$ C-labeled DNA from A. tumefaciens TT111 $\times$ DNA from Pseudomonas coronafaciens NCPPB 1328 (type V).

there was a positive correlation between the $T_{m(e)}$ of the DNA:rRNA hybrids and the overall phenotypic similarity of the genera involved. The percentage of rRNA binding helps to distinguish genera at the same $T_{m(e)}$ level. The phenotypic similarity between Agrobacterium and Rhizobium is well known. The $T_{m(e)}$ values of their intergeneric DNA:rRNA hybrids in stringent conditions are high.

Another argument comes from the strains which we received under the erroneous generic names Achromobacter hartlebii NCIB 8129 (number 65), Alcaligenes AB 940 (number 67), and the presumed agrobacteria AB 1196 and 
$\mathrm{AB} 1293$ (numbers 66 and 68). The three $\mathrm{AB}$ strains are identical or almost identical because of their high DNA homology (over 90\%, unpublished data), and almost identical protein electropherograms (Fig. 6). They have been isolated from pleural fluid (AB 1196), sputum (AB 1293), and spinal fluid (AB 940) in Denmark ( $H$. Lautrop, personal communication); they are probably casual contaminants, rather than causal pathogens. The Achromobacter hartlebii organism NCIB 8129 was presumably isolated in the United States; no further information on its origin was available. On phenotypic grounds these four organisms, in particular strain NCIB 8129, were suspected to be either Agrobacterium or closely related to it $(36,42,72)$. The Achromobacter hartlebii strain was probably for this reason reclassified (wrongly, according to our results) as Agrobacterium sp. in the Catalogue of Strains (5). All four strains form DNA:rRNA hybrids of high $T_{m(e)}$ with Agrobacterium. There is thus a distinct correlation be-
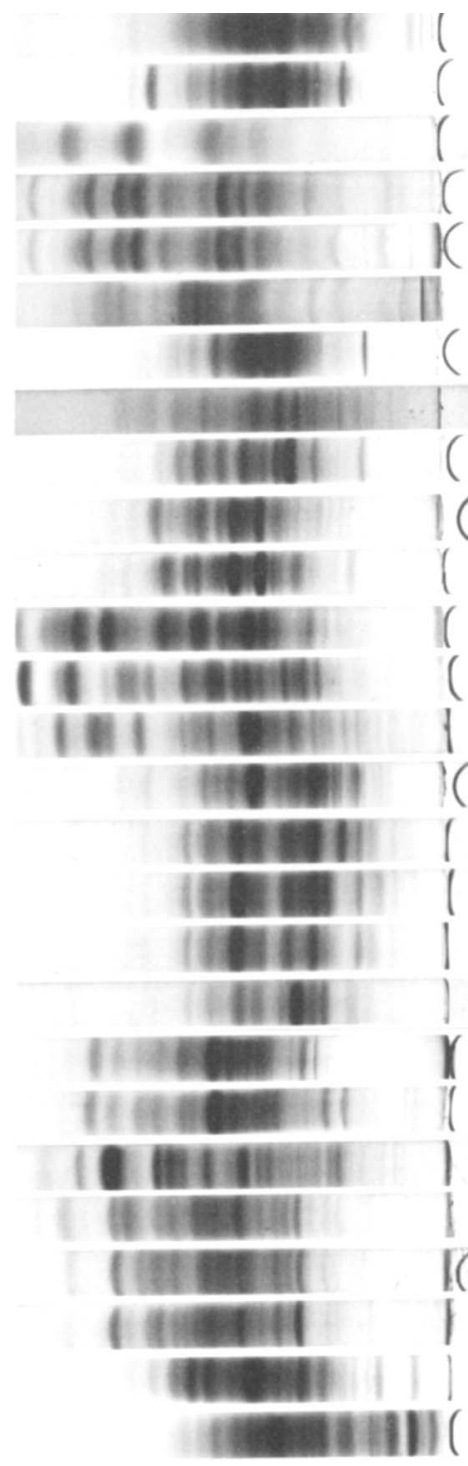

"Agrobacterium" Sundman K17 "Agrobacterium" Sundman 08 "Agrobacterium" Sundman M14 "Agrobacterium" "pseudotsugae" NCPPB 180 "Agrobacterium" "pseudotsugae" ATCC 13330 "Agrobacterium" "gypsophilae" ATCC 13329 "Agrobacterium" azotophilum Agrobacterium rhizogenes ICPB TR101 Agrobacterium tumefaciens ICPB TT111 Agrobacterium radiobacter $\$ 1005$ "Azotomonas" "insolita" NCIB 9749 Azotomonas fluorescens NCIB 9884 Mycoplana bullata NCIB 9440 Mycoplana dimorpha NCIB 9439 Phyllobacterium rubiacearum $L M G_{1} t_{1}$ Phyllobacterium myrsinacearum LMG2 t2 Phyllobacterium myrsinacearum LMG $2 t_{1}$ Phyllobacterium myrsinacearum $L_{M G} \mathrm{t}_{1}$ Phyllobacterium myrsinacearum $\mathrm{LMG}_{3} \mathrm{t}_{2}$ "Chromobacterium" "lividum" NCTC 10590 "Chromobacterium" "lividum" NCTC 10591 "Achromobacter" hartlebii NCIB 8129 "Alcaligenes" spec. AB940 "Achromobacter" spec. AB1196 "Achromobacter" spec. AB1293 Alcaligenes faecalis NCIB 8156 Alcaligenes denitrificans ATCC 15173

FIG. 6. Electropherograms of soluble proteins from a few reference strains of Agrobacterium, Alcaligenes faecalis, and Alcaligenes denitrificans, several misnamed "Agrobacterium" strains, and taxa related to Agrobacterium andlor Rhizobium. The method of Kersters and De Ley (41) was followed. Also used were unpublished data from the same authors. 
tween $T_{m(e)}$ and phenotypic similarity. Although these four organisms are related to Agrobacterium, they definitely are not members of this genus. Their protein electropherograms (Fig. 6) are different from the electropherograms of over 200 authentic agrobacteria (Kersters and De Ley, unpublished data). They are likewise neither Alcaligenes nor Achromobacter, because of the type of gluconate metabolism (22) and of their quite different protein electropherograms (Fig. 6). These four strains are far removed from the Alcaligenes area in Fig. 3. They must be renamed, but we prefer to wait until more information becomes available.

There are three other genera whose rRNA similarity overlaps with Agrobacterium and the peritrichous Rhizobium, namely Azotomonas, Mycoplana, and Phyllobacterium. Their taxonomic positions are uncertain; they are not mentioned in Bergey's Manual of Determinative Bacteriology (9). The genus name Azotomonas was created by Stapp (66) for freeliving nitrogen-fixing coccoids and rods from soil, with one to three polar flagella. Neither of the two organisms, Azotomonas fluorescens NCIB 9884 and Azotomonas insolita NCIB 9749, conforms to this description. They both have two to four peritrichous flagella (15), and they do not fix nitrogen $(37,59)$. Azotomonas is a genus of uncertain status. The position of the strain Azotomonas insolita NCIB 9749 in the Agrobacterium area (Fig. 3) suggested that it was misnamed. We confirmed by DNA:DNA hybridization (Table 6) and by protein electrophoresis (Fig. 6) that it is indeed an Agrobacterium of cluster 1. Azotomonas fluorescens NCIB 9884 is not an Agrobacterium. The genus name Mycoplana was created by Gray and Thornton (31) to include motile branching cells, able to attack phenol. Both species Mycoplana bullata NCIB 9440 and Mycoplana dimorpha NCIB 9439 were isolated from soil. The genus name Phyllobacterium was created by Knösel $(45,46)$ for bacteria isolated from leaf nodules of
Rubiaceae, Myrsinaceae, etc. We used Phyllobacterium rubiacearum isolated from Pavetta zimmermania, and Phyllobacterium myrsinacearum isolated from Ardisia crispa and Ardisia crenata. The protein electropherograms of each of the five Phyllobacterium strains are very similar (Fig. 6), strongly suggesting that they are phenotypically very similar, although they were isolated from three different plant species. The rRNA parameters of the five strains are very close and overlap with these of the peritrichous Rhizobium. Knösel $(45,46)$ located Phyllobacterium in the family of the Rhizobiaceae.

It is quite remarkable and perhaps not a coincidence that the rRNA features of two misnamed Chromobacterium lividum (Chromobacterium folium) strains, NCTC 10590 and 10591, are in the vicinity of the Phyllobacterium rRNA area. These strains were isolated from germinating seeds of, and are present in, leaf nodules of Psychotria nairobensis and Ardisia crispa, respectively (4). They might be related to Phyllobacterium (38), but they are not identical with the latter genus (Fig. 3 and 6). Both strains fall quite outside the rRNA area of authentic Chromobacterium strains. This was also true when their DNA was hybridized with ${ }^{14} \mathrm{C}$ labeled rRNA from the authentic neotype strains of Chromobacterium violaceum and Chromobacterium lividum (J. De Ley and P. Segers, manuscript in preparation). Our results show that both strains NCTC 10590 and 10591 should be severed from Chromobacterium. Several phenotypic differences in support of our genotypic results were collected in Table 7 . The appropriate generic name of both Chromobacterium folium strains will have to be decided later.

Azotomonas fluorescens NCIB 9884, Mycoplana, Phyllobacterium, the Achromobacter hartlebii organism NCIB 8129 , the strains AB 940, AB 1196, AB 1293 (and perhaps the Chromobacterium folium organisms) display weak

TABLE 7. Some phenotypic differences between authentic Chromobacterium lividum strains and the supposed chromobacteria from leaf nodulated plants ${ }^{a}$

\begin{tabular}{|c|c|c|}
\hline Feature & $\begin{array}{c}\text { Authentic Chromobacterium } \\
\text { lividum }\end{array}$ & Strains NCTC 10590 and 10591 \\
\hline $\mathrm{Mol} \% \mathrm{G}+\mathrm{C}$ & $65-72$ & 61 and 63 \\
\hline $\mathrm{N}_{2}$ fixation & Not reported & + \\
\hline Habitat & $\begin{array}{l}\text { Common in soil and water in } \\
\text { temperate regions }\end{array}$ & $\begin{array}{l}\text { Leaf-nodulated Ardisia crispa, } \\
\text { Psychotria nairobensis, and } \\
\text { others }\end{array}$ \\
\hline Pigment & Violacein & Nature not determined \\
\hline $\begin{array}{l}\text { Attack on fructose, glucose, ga- } \\
\text { lactose, arabinose, xylose, } \\
\text { maltose, sorbitol, inositol }\end{array}$ & Oxidative & No attack \\
\hline
\end{tabular}

${ }^{a}$ Data taken from references 4 and 9. 
but distinct DNA similarities with Agrobacterium (Table 6), with type III and IV melting curves testifying to their remote relationship to this genus. From all of the above data we conclude that these organisms belong in the family of the Rhizobiaceae, together with Agrobacterium and Rhizobium.

The next lower degree of rRNA relationship consists of the acetic acid bacteria, Zymomonas and Beijerinckia, with a $\Delta T_{m(e)}$ of about $14^{\circ} \mathrm{C}$. It may be significant to note that most organisms with a $T_{m(e)}$ above $65^{\circ} \mathrm{C}$ are associated with plants. This may point to a common evolutionary origin.

When there are more mismatchings in the DNA:rRNA hybrid, and the $T_{m(e)}$ falls below $65^{\circ} \mathrm{C}$, the taxonomic distances increase. From hybridizations with ${ }^{14} \mathrm{C}$-labeled rRNA from other gram-negative bacteria, it likewise appeared that this temperature is a lower limit for significant taxonomic conclusions, below which all foreign taxa are located together in a confused mass of overlapping rRNA areas (De Ley et al., manuscript in preparation). The instability of the DNA:rRNA hybrids of Agrobacterium with the Enterobacteriaceae, Azotobacter, Azomonas, Pseudomonas, the Alcaligenes-Bordetella bronchiseptica group, Aeromonas, Chromobacterium, Bacillus, Campylobacter, Arthrobacter, Corynebacterium, Microbacterium, Nocardia, and Mycobacterium rhodochrous (Fig. 3 and 4) agrees with the known facts that these taxa are phenotypically very different from Agrobactirium. The reverse hybridizations of Agrobacterium DNA with ${ }^{14} \mathrm{C}$-labeled rRNA from several organisms (Table 5) allow the same conclusion.

Skyring and Quadling (63) suggested, from their principal component analysis of a variety of soil bacteria, that Arthrobacter is a rather close relative of Agrobacterium and Rhizobium. To check this assumption we tested quite a number of coryneforms. The rRNA cistrons of all of them are quite different from Agrobacterium and Rhizobium. A thorough examination of Skyring's and Quadling's (63) data disclosed that, after the first clustering cycle, quite a number of clusters (for example, 104, 107, 109, 112 , etc.) were very heterogeneous and contained many foreign intruders; after the second clustering cycle the groups become even more heterogeneous. This procedure may be very useful to identify soil bacteria, but it seems unsuitable for taxonomic conclusions.

"Achromobacter" strains Ruiter 1 and 5 (numbers 69 and 70) cause browning of marinated herring (60). The taxonomic position of these organisms remained uncertain in spite of Ruiter's proposal that they probably belong in
Achromobacter anitratus. We established (De Ley et al., unpublished data) that they belong in the Enterobacteriaceae. Their hybrid parameters with Agrobacterium ${ }^{14} \mathrm{C}$-labeled rRNA fall indeed into this family.

The genus Agrobacterium had its share of misnamed strains and species. We checked quite a number of them by rRNA hybridization. One expects that all of these strains will fall outside the Agrobacterium area, and they do.

Bacterium gypsophilae was isolated from galls on Gypsophila plants and described by Brown in 1934 (8). It was renamed Agrobacterium by Starr and Weiss (67). There is convincing evidence that these organisms belong in Erwinia herbicola $(18,30$; De Ley and De Smedt, manuscript in preparation). We used one of Brown's original strains (ATCC 13329) and two strains, IPO 445 and IPO $280 \mathrm{e}$, isolated from roses in the Netherlands in 1969 and 1964, respectively. The DNA:rRNA parameters put these three strains correctly in the Enterobacteriaceae. Strain IPO 280e forms no DNA:DNA hybrid with Agrobacterium (Table 6). The protein electropherogram of strain ATCC 13329 shows that it is not an Agrobacterium (Fig. 6).

Hansen and Smith (34) isolated Bacterium pseudotsugae from gall diseases on Douglas fir; this organism was renamed Agrobacterium by Săvulescu (61). "A." pseudotsugae NCPPB 180 had a DNA quite different from other agrobacteria (18). Therefore, its taxonomic position became doubtful. This strain displayed about the same biochemical reactions as Arthrobacter (morphology, pathogenicity, etc., were not tested; 64), but this could not be considered as proof of taxonomic identity, because of the clustering techniques (63) as mentioned above. The DNA:rRNA parameters of our two strains of "Agrobacterium" pseudotsugae (numbers 114 and 115) located them among the coryneforms, in the vicinity of several authentic Arthrobacter strains. The protein electropherograms of both strains NCPPB 180 and ATCC 13330 are almost identical to each other and are different from Agrobacterium (Fig. 6).

Ahrens (1) and Ahrens and Rheinheimer (2) isolated from the Baltic Sea several bacteria, which they at first classified in seven new species in Agrobacterium. Fortunately Ahrens withdrew this proposal (9). We completely agree with this withdrawal: the genus Agrobacterium has been under investigation in our laboratory for the last two decades and none of the hundreds of authentic strains from all over the world resemble phenotypically or genotypically any of Ahrens' organisms. The results presented in the present paper again support this conclusion. The DNA:rRNA parameters of 
Ahrens' strains do not place them in Agrobacterium. "Agrobacterium" agile A 82 (number 32) has rRNA characteristics close to Pseudomonas (J. De Ley and P. De Vos, manuscript in preparation). "A." ferrugineum A43 (number 27), and "A." kieliense B9 (number 28) seem to belong in the vicinity of the peritrichous Rhizobium, Mycoplana, Phyllobacterium, and the $\mathrm{AB}$ strains (Fig. 3). It seems to us that both organisms belong in the family of the Rhizobiaceae, but their exact taxonomic position is unknown. The remaining strains "A." luteum B14, "A." gelatinovorum B6, and "A." aggregatum B1 (numbers 29, 30, and 31) are much less related. Since Ahrens' strains and Agrobacterium require different growth media, no comparable protein electropherograms could be prepared. Our data do not support the tentative suggestion of Hendrie et al. (36) that Ahrens' strains might belong in Alcaligenes.

V. Sundman $(68,69)$ isolated and described several lignanolytic bacteria from Finland, such as strains K17 (NCIB 10467) from decaying sawdust, 08 (NCIB 10469) from decaying brushwood, and M14 (NCIB 10468) from forest soil. These organisms were all tentatively included in Agrobacterium $(68,69)$. In our experience, however, phenotypic features (Kersters and De Ley, unpublished data), protein electropherograms (Fig. 6), DNA:DNA hybridization (Table 6), and DNA:rRNA hybridization (Fig. 3 ) excluded these three strains from the latter genus. Strains K17 and 08 are almost identical (Fig. 6). The strains 08 and M14 (numbers 33 and 34) did not fall in the Agrobacterium area. Strain 08 cannot be identified from its position in Fig. 3, but we know from other data that both $\mathrm{K} 17$ and 08 are taxonomically not far removed from Alcaligenes (De Ley and Segers, unpublished data). Strain M14 is even less related to Agrobacterium and we have not been able to identify it; we only know it does not belong in the Rhizobiaceae, the Enterobacteriaceae, the Vibrionaceae, the Pseudomonadaceae, the Azotobacteriaceae, Alcaligenes, or Arthrobacter (De Ley et al., unpublished data).

Ulloa and Herrera (73) isolated and described bacteria from pozol (fermented maize dough, used as food in Southwest Mexico); one of the strains was called Agrobacterium azotophilum. Its ability to fix atmospheric $\mathrm{N}_{2}$ was stressed (70). The description given by these authors, the position of the strain on the rRNA similarity map (Fig. 3), its lack of DNA homology with Agrobacterium (Table 6), and its protein electrophoregram (Fig. 6) show, however, that this organism does not belong in Agrobacterium.

The approach which we have explored has thus not only taxonomic, but also diagnostic value: we established that a number of organisms were mislabeled as Agrobacterium: (i) the pseudotsugae strains, (ii) the gypsophilae strains, (iii) Ahrens' strains from the Baltic Sea, (iv) Sundman's lignanolytic strains, and (v) Ulloa and Herrera's strain from Mexican pozol.

\section{ACKNOWLEDGMENTS}

J.D.L. thanks the Fonds voor Kollektief Fundamenteel Onderzoek for research and personnel grants. J.D.S. is indebted to the same Fonds for a scholarship. We are indebted to all the individuals and institutes who kindly provided strains.

\section{REPRINT REQUESTS}

Address requests for reprints to: Prof. J. De Ley, Laboratory of Microbiology, R.U.G., K.L. Ledeganckstraat 35, B9000 Gent, Belgium.

\section{LITERATURE CITED}

1. Ahrens, R. 1968. Taxonomische Untersuchungen an sternbildenden Agrobacterium-Arten aus der westlichen Ostzee. Kiel. Meeresforsch. 24:147-173.

2. Ahrens, R., and G. Rheinheimer. 1967. Ueber einige sternbildende Bakterien aus der Ostsee. Kiel. Meeresforsch. 23:127-136.

3. Ambler, R. P. 1973. Bacterial cytochromes c and molecular evolution. Syst. Zool. 22:554-565.

4. Bettelheim, K. A., J. F. Gordon, and J. Taylor. 1968 The detection of a strain of Chromobacterium lividum in the tissues of certain leaf-nodulated plants by the immunofluorescence technique. J. Gen. Microbiol. 54:177-184.

5. Bousfield, I. J., and S. D. Graham (ed.). 1975. The national collection of industrial bacteria, catalogue of strains. Her Majesty's Statistics Office, London.

6. Bray, G. A. 1960 . A simple efficient liquid scintillator for counting aqueous solutions in a liquid scintillation counter. Anal. Biochem. 1:279-285.

7. Brenner, D. J. 1973. Deoxyribonucleic acid reassociation in the taxonomy of enteric bacteria. Int. J. Syst. Bacteriol. 23:298-307.

8. Brown, N. 1934. A gall similar to crown gall produced on Gypsophila by a new bacterium. J. Agric. Res. 48:1099-1112.

9. Buchanan, R. E., and N. E. Gibbons (ed.). 1974. Bergey's manual of determinative bacteriology. The Williams \& Wilkins Co., Baltimore.

10. Burton, K. 1956. A study of the conditions and mechanism of the diphenylamine reaction for the colorimetric estimation of deoxyribonucleic acid. Biochem. J. 62:315-323.

11. Crombach, W. H. J. 1972. DNA base composition of soil arthrobacters and other coryneforms from cheese and sea fish. Antonie van Leeuwenhoek J. Microbiol. Serol. 38:105-120.

12. Dayhoff, M. O. 1972. Atlas of protein sequence and structure, vol. 5. National Biomedical Research Foundation, Silver Spring, Md.

13. De Ley, J. 1962. Comparative biochemistry and enzymology in bacterial classification, p. 164-195. In G. C. Ainsworth and P. H. A. Sneath (ed.), Microbial classification. 12th Symposium of the Society for General Microbiology. Cambridge University Press, Cambridge, England.

14. De Ley, J. 1968. Molecular biology and bacterial phylogeny, p. 103-156. In T. Dobzhansky, M. K. Hecht, and W. C. Steere (ed.), Evolutionary biology, vol. 2. Appleton-Century-Crofts, New York. 
15. De Ley, J. 1968. DNA base composition and classification of some more free-living nitrogen-fixing bacteria. Antonie van Leeuwenhoek J. Microbiol. Serol. 34:66-70.

16. De Ley, J. 1972. Agrobacterium: intrageneric relationships and evolution, p. 251-259. In Proceedings of the Third International Conference on Plant Pathology and Bacteriology, Wageningen, 1971. Pudoc, Wageningen, the Netherlands.

17. De Ley, J. 1974. Phylogeny of procaryotes. Taxon 23:291-300.

18. De Ley, J., M. Bernaerts, A. Rassel, and J. Guilmot. 1966. An approach to an improved taxonomy of the genus Agrobacterium. J. Gen. Microbiol. 43:7-17.

19. De Ley, J., H. Cattoir, and A. Reynaerts. 1970. The quantitative measurement of DNA hybridization from renaturation rates. Eur. J. Biochem. 12:133142.

20. De Ley, J., and J. De Smedt. 1975. Improvements of the membrane filter method for DNA:rRNA hybridization. Antonie van Leeuwenhoek J. Microbiol. Serol. 41:287-307.

21. De Ley, J., and K. Kersters. 1975. Biochemical evolution in bacteria, p. 1-77. In M. Florkin and E. $\mathbf{H}$. Stotz (ed.), Comprehensive biochemistry, vol. 29B. Elsevier Scientific Publishing Co., Amsterdam.

22. De Ley, J., K. Kersters, J. Khan-Matsubara, and J. M. Shewan. 1970. Comparative D-gluconate metabolism and DNA base composition in Achromobacter and Alcaligenes. Antonie van Leeuwenhoek J. Microbiol. Serol. 36:193-207.

23. De Ley, J., and A. Rassel. 1965. DNA base composition, flagellation and taxonomy of the genus Rhizobium. J. Gen. Microbiol. 41:85-91.

24. De Ley, J., and R. Tytgat. 1970. Evaluation of membrane filter methods for DNA-DNA hybridization. Antonie van Leeuwenhoek J. Microbiol. Serol. 36:461-474

25. De Ley, J., R. Tytgat, J. De Smedt, and M. Michiels. 1973. Thermal stability of DNA:DNA hybrids within the genus Agrobacterium. J. Gen. Microbiol. 78:241252.

26. Doi, R. H., and R. T. Igarashi. 1965. Conservation of ribosomal and messenger ribonucleic acid cistrons in Bacillus species. J. Bacteriol. 90:384-390.

27. Dubnau, D., I. Smith, P. Morell, and J. Marmur. 1965. Gene conservation in Bacillus species. 1. Conserved genetic and nucleic acid base sequence homologies. Proc. Natl. Acad. Sci. U.S.A. 54:491-498.

28. Gillis, M., J. De Ley, and M. De Cleene. 1970. The determination of molecular weight of bacterial genome DNA from renaturation rates. Eur. J. Biochem. 12:143-153.

29. Graham, P. H. 1964. The application of computer techniques to the taxonomy of the root-nodule bacteria of legumes. J. Gen. Microbiol. 35:511-517.

30. Graham, D. C., and E. C. Quinn. 1974. Identification of Agrobacterium gypsophilae strains NCPPB 179 and NCPPB 1948 as Erwinia herbicola. Int. J. Syst. Bacteriol. 24:238-241.

31. Gray, P. H. H., and H. G. Thornton. 1928. Soil bacteria that decompose certain aromatic compounds. Zentralbl. Bakteriol. Parasitenkd. Infektionskr. Hyg. Abt. 2 73:74-96.

32. Grienenberger, J. M., and D. Simon. 1972. Etude de la structure et de la dégradation des acides ribonucléiques ribosomaux de quelques bactéries du genre Agrobacterium. C. R. Acad. Sci. Ser. D. 274:13991402 .

33. Grienenberger, J. M., and D. Simon. 1975. Structure and biosynthesis of the ribosomal ribonucleic acids from the oncogenic bacterium Agrobacterium tumefaciens. Biochem. J. 149:23-30.

34. Hansen, H. N., and R. E. Smith. 1937. A bacterial gall disease of Douglas fir Pseudotsuga taxifolia. Hilgardia 10:569-577.

35. Heberlein, G. T., J. De Ley, and R. Tytgat. 1967. Deoxyribonucleic acid homology and taxonomy of Agrobacterium, Rhizobium and Chromobacterium. J. Bacteriol. 94:116-124.

36. Hendrie, M. S., A. J. Holding, and J. M. Shewan. 1974. Emended description of the genus Alcaligenes and of Alcaligenes faecalis and proposal that the generic name Achromobacter be rejected: the status of the named species of Alcaligenes and Achromobacter. Int. J. Syst. Bacteriol. 24:534-550.

37. Hill, S., and J. R. Postgate. 1969. Failure of putative nitrogen-fixing bacteria to fix nitrogen. J. Gen. Microbiol. 58:277-285.

38. Horner, H. T., and N. R. Lersten. 1972. Nomenclature of bacteria in leaf nodules of the families Myrsinaceae and Rubiaceae. Int. J. Syst. Bacteriol. 22:117-122.

39. Johnson, J. L., R. S. Anderson, and E. J. Ordal. 1970 Nucleic acid homologies among oxidase-negative Moraxella species. J. Bacteriol. 101:568-573.

40. Johnson, J. L., and B. S. Francis. 1975. Taxonomy of the clostridia: ribosomal ribonucleic acid homologies among the species. J. Gen. Microbiol. 88:229-244.

41. Kersters, K., and J. De Ley. 1975. Identification and grouping of bacteria by numerical analysis of their electrophoretic protein patterns. J. Gen. Microbiol. 87:333-342.

42. Kersters, K., J. De Ley, P. H. A. Sneath, and M. Sackin. 1973. Numerical taxonomic analysis of Agrobacterium. J. Gen. Microbiol. 78:227-239.

43. Kirby, K. S. 1957 . A new method for the isolation of deoxyribonucleic acids; evidence on the nature of bonds between deoxyribonucleic acid and protein. Biochem. J. 66:495-504.

44. Kirby, K. S., E. Fox-Carter, and M. Guest. 1967. Isolation of deoxyribonucleic acid and ribosomal ribonucleic acid from bacteria. Biochem. J. 104:258-262.

45. Knösel, D. 1962 . Untersuchungen an sternbildenden Bakterien. Arbeiten der Landwirtschaftlichen Hochschule Hohenheim, vol. 15. Verlag Eugen Ulmer, Stuttgart.

46. Knösel, D. 1962. Prüfung von Bakterien auf Fähigkeit zur Sternbildung. Zentralbl. Bakteriol. Parasitenkd. Infektionskr. Hyg. Abt. 2 116:79-100.

47. Larsen, P. O., and M. Zaitlin. 1971. Studies on the nucleic acids of avirulent, attenuated, and virulent isolates of Agrobacterium tumefaciens. Phytopathology 61:337-338.

48. LeGoff, L. 1968. Acides ribonucléiques des bactéries du crown-gall Agrobacterium tumefaciens (Smith et Town) Conn. exposées au borate de sodium. Ann. Inst. Pasteur Paris 115:232-248.

49. Margoliash, E., W. M. Fitch, and R. E. Dickerson. 1971. Molecular expression of evolutionary phenomena in the primary and tertiary structures of cytochrome c, p. 52-95. In E. Schoffeniels (ed.), Biochemical evolution and the origin of life. North-Holland Publishing Co., Amsterdam.

50. Marmur, J. 1961. A procedure for the isolation of deoxyribonucleic acid from micro-organisms. J. Mol. Biol. 3:208-218.

51. Meys, W. H., and R. A. Schilperoort. 1971. Determination of the amount of DNA on nitrocellulose membrane filters. FEBS Lett. 12:166-168.

52. Midgley, J. E. M. 1965. Effects of different extraction procedures on the molecular characteristics of riboscmal ribonucleic acid. Biochim. Biophys. Acta 95:232-243.

53. Moore, R. L., and B. J. McCarthy. 1967. Comparative study of ribosomal ribonucleic acid cistrons in enterobacteria and myxobacteria. J. Bacteriol. 94:10661074.

54. Moore, R. L., and B. J. McCarthy. 1969. Base sequence 
homology and renaturation studies of the deoxyribonucleic acid of extremely halophilic bacteria. J. Bacteriol. 99:255-262.

55. Noll, H., and E. Stutz. 1968. The use of sodium and lithium dodecyl sulfate in ribonucleic acid isolation. Methods Enzymol. 12B:129-155.

56. Pace, B., and L. L. Campbell. 1971. Homology of ribosomal ribonucleic acid of Desulfovibrio species with Desulfovibrio vulgaris. J. Bacteriol. 106:717-719.

57. Pace, B., and L. L. Campbell. 1971. Homology of ribosomal ribonucleic acid of diverse bacterial species with Escherichia coli and Bacillus stearothermophilus. J. Bacteriol. 107:543-547.

58. Palleroni, N. J., R. Kunisawa, R. Contopoulou, and M. Doudoroff. 1973. Nucleic acid homologies in the genus Pseudomonas. Int. J. Syst. Bacteriol. 23:333-339.

59. Parejko, R. A., and P. W. Wilson. 1968. Taxonomy of Azotomonas species. J. Bacteriol. 95:143-146.

60. Ruiter, A. 1963. Ueber eine braune Verfärbung von mariniertem Hering. Dtsch. Lebensm. Rundsch., April, p. 110-111.

61. Săvulescu, T. 1947. Contribution à la classification des Bactériacées phytopathogènes. Ann. Acad. Romane Ser. III 22:1-26.

62. Schuch, W., and U. E. Loening. 1975. The ribosomal ribonucleic acid of Agrobacterium tumefaciens. Biochem. J. 149:17-22.

63. Skyring, G. W., and C. Quadling. 1969. Soil bacteria: principal component analysis of descriptions of named cultures. Can. J. Microbiol. 15:141-158.

64. Skyring, G. W., C. Quadling, and J. W. Rouatt. 1971. Soil bacteria: principal component analysis of physiological descriptions of some named cultures of Agro- bacterium, Arthrobacter, and Rhizobium. Can. J. Microbiol. 17:1299-1311.

65. Sokal, R., and P. H. A. Sneath. 1963. Principles of numerical taxonomy. Freeman and Co., San Francisco.

66. Stapp, C. 1940. Azotomonas insolita, ein neuer aerober stickstoffbindender Mikro-organismus. Zentralbl. Bakteriol. Parasitenkd. Infektionskr. Hyg. Abt. 2 102:1-19.

67. Starr, M. P., and J. E. Weiss. 1943. Growth of phytopathogenic bacteria in a synthetic asparagin medium. Phytopathology 33:314-318.

68. Sundman, V. 1964. A description of some lignanolytic soil bacteria and their ability to oxidize simple phenolic compounds. J. Gen. Microbiol. 36:171-183.

69. Sundman, V. 1965. A study of lignanolytic soil bacteria with special reference to $\alpha$-conidendrin decomposition. Acta Polytech. Scand., Chemistry Incl. Metall. Ser. 40:116.

70. Taboada, J., M. Ulloa, and T. Herrera. 1973. Fijación de nitrógeno in vitro por Agrobacterium azotophilum en diversos substratos, principalmente tierra y derivados de la industria azucarera. Rev. Latinoam. Microbiol. 15:143-146.

71. Takahashi, H., H. Saito, and Y. Ikeda. 1967. Species specificity of the ribosomal RNA cistrons in bacteria. Biochim. Biophys. Acta 134:124-133.

72. Thornley, M. J. 1967. A taxonomic study of Acinetobacter and related genera. J. Gen. Microbiol, 49:211-257.

73. Ulloa, M., and T. Herrera. 1972. Descripción de dos especies nuevas de bacterias aisladas del pozol: Agrobacterium azotophilum y Achromobacter pozolis. Rev. Latinoam. Microbiol. 14:15-24. 